IZA DP No. 8426

Too Busy for School?

The Effect of Athletic Participation on Absenteeism

Harold E. Cuffe

Glen R. Waddell

Wesley Bignell

August 2014 


\title{
Too Busy for School? The Effect of Athletic Participation on Absenteeism
}

\author{
Harold E. Cuffe \\ Victoria University of Wellington \\ Glen R. Waddell \\ University of Oregon \\ and IZA \\ Wesley Bignell \\ University of Washington
}

\section{Discussion Paper No. 8426 \\ August 2014}

\author{
IZA \\ P.O. Box 7240 \\ 53072 Bonn \\ Germany \\ Phone: +49-228-3894-0 \\ Fax: +49-228-3894-180 \\ E-mail: iza@iza.org
}

\begin{abstract}
Any opinions expressed here are those of the author(s) and not those of IZA. Research published in this series may include views on policy, but the institute itself takes no institutional policy positions. The IZA research network is committed to the IZA Guiding Principles of Research Integrity.

The Institute for the Study of Labor (IZA) in Bonn is a local and virtual international research center and a place of communication between science, politics and business. IZA is an independent nonprofit organization supported by Deutsche Post Foundation. The center is associated with the University of Bonn and offers a stimulating research environment through its international network, workshops and conferences, data service, project support, research visits and doctoral program. IZA engages in (i) original and internationally competitive research in all fields of labor economics, (ii) development of policy concepts, and (iii) dissemination of research results and concepts to the interested public.
\end{abstract}

IZA Discussion Papers often represent preliminary work and are circulated to encourage discussion. Citation of such a paper should account for its provisional character. A revised version may be available directly from the author. 


\section{ABSTRACT \\ Too Busy for School? \\ The Effect of Athletic Participation on Absenteeism*}

While existing research supports that participation in high-school athletics is associated with better education and labour-market outcomes, the mechanisms through which these benefits accrue are not well established. We use data from a large public-school district to retrieve an estimate of the causal effect of high-school athletic participation on absenteeism. We show that active competition decreases absences, with most of the effect driven by reductions in unexcused absences - truancy among active male athletes declines significantly, with the effects larger in earlier grades and for black and Hispanic boys. Strong game-day effects are also evident, in both boys and girls, as truancy declines on game days are offset with higher rates of absenteeism the following day. Addressing the effects on academic performance, we find significant heterogeneity in the response to active athletic participation by race, gender and family structure, with boys not in dual-parent households exhibiting small academic improvements in semesters in which they experienced greater athletic participation.

JEL Classification: I21, L83

Keywords: education, truancy, attendance, athletes, sport

Corresponding author:

Glen R. Waddell

Department of Economics

University of Oregon

Eugene, OR 97403-1285

USA

E-mail: waddell@uoregon.edu

\footnotetext{
* The views expressed in this paper represent those of the authors and should not be interpreted as representing those held by Seattle Public Schools or any other representative or employee of Seattle Public Schools. While retaining responsibility for any shortcomings, the authors thank seminar participants at Virginia (Batton), Victoria University of Wellington, the 24th New Zealand Econometric Study Group Meeting, and Colorado-Denver.
} 
But here's the thing: most American principals I spoke with expressed no outrage over the primacy of sports in school. In fact, they fiercely defended it. "If I could wave a magic wand, I'd have more athletic opportunities for students, not less," Bigham, the former Tennessee principal, told me. His argument is a familiar one: sports can be bait for students who otherwise might not care about school. "I've seen truancy issues completely turned around once students begin playing sports," he says. "When students have a sense of belonging, when they feel tied to the school, they feel more part of the process." (Amanda Ripley, "The Case Against High-School Sports," The Atlantic, October 2013.)

\section{Introduction}

In the 2012-13 academic year, more than 12-percent of boys in grades nine through twelve participated in high school football. Overall, it marks the 24th consecutive year of increase in high-school athletic participation, with track and field, basketball, soccer, and baseball/softball each attracting more than 1 million student athletes. ${ }^{1}$ At the same time, however, there is growing concern among parents and policy makers, who question the efficacy of participation and the potential imbalance represented in the escalating pursuit of non-academic activities within American educational institutions. Clearly, a better understanding of the implicit tradeoffs associated with athletic participation is fundamental to navigating any future provisions of athletic opportunities. Our contribution will be to move us in that direction.

The related academic literature suggests that high levels of participation are not without justification. In fact, the metanarrative is quite clearly that participation in high-school athletics correlates with or contributes to improvements in outcomes. For example, existing research broadly implicates athletic participation in better labour-market outcomes (Barron, Ewing and Waddell, 2000; Eide and Ronan, 2001; Stevenson, 2010), higher high-school GPA, standardized-test performance, and class rank (Barron, Ewing and Waddell, 2000; Lipscomb, 2007; Rees and Sabia, 2010), and more-favourable in high-school and college degree attain-

\footnotetext{
${ }^{1}$ National Federation of State High School Associations (NFHS), www.nfhs.org, and the National Center for Education Statistics, http://nces.ed.gov.
} 
ment (Barron, Ewing and Waddell, 2000; Eide and Ronan, 2001; Lipscomb, 2007; Pfeifer and Cornelißen, 2010; Stevenson, 2010). Persico, Postlewaite and Silverman (2004) report that high school athletics participation plays a significant role in explaining the adult wage premium associated with greater youth height. Yet, in conducting sound policy in this area it is important that one be able to identify the underlying mechanisms that has athletic participation leading to positive outcomes. As athletic funding comes under increasing scrutiny, knowing the channels through which benefits might derive should predate policy initiatives that would change the way such activities are governed. Likewise, as head-injury risk jeopardizes the continuation of some sports as we know them, an appropriate characterization of the cost-benefit exercise should reflect the full set of mechanisms through which athletics can contribute to outcomes.

In this paper, we begin by considering the effect of athletic participation on one such mechanism - student-athlete absenteeism. While the consequences of student absenteeism have not been directly identified in the literature, there is evidence supporting that instructional time may itself be an important factor in educational achievement. For example, in a country-level design, Lee and Barro (2001) find that more time in school improves math and science test scores although reading scores may suffer. Using international survey data, Lavy (2012) and Rivkin and Schiman (2013) leverage within-school across-subject variation in weekly instruction time and find positive effects on standardized-test scores.

Quasi-experimental evidence in Pischke (2007) indicates that German student cohorts exposed to shorter school years exhibit lower academic achievement and higher rates of grade repetition, holding curriculum constant. Eren and Millimet (2007) report weak evidence that longer school years improve math and reading test scores, which they identify from variation across US states. Using within-state variation in unscheduled school closures, Marcotte and Hemelt (2008) find that the percentage of students passing math assessments falls by about one-third to one-half a percentage point for each day school is closed, with the effect largest 
for students in lower grades. Exploiting weather closures as a source of exogenous variation, Marcotte (2007) suggests that the share of students testing proficient in winters with average levels of snowfall (about 17 inches) is about one to two percentage points lower than in winters with little to no snow. With a similar identification strategy, Marcotte and Hansen (2010) suggests that a 10-day increase in instructional days yields a 0.2 standard-deviation increase in state math assessments, or the equivalent of a three- to five-percentage-point decline in the number of students passing math assessments. Using state-mandated changes in test-date administration in Minnesota, which moved five times in five years, Hansen (2011) also shows that more instructional time prior to test administration increases student performance.

Overall, we are inclined to interpret such evidence as lower-bound estimates of the true effect of absenteeism on educational achievement, since absenteeism arguably represents both a reduction in instructional days plus the misalignment of a student's progression in coursework and that of the class. ${ }^{2}$ Among the high-school students contributing to our analysis, 97 percent report having an absence of some kind every year, while more than 85 percent report having an unexcused absence in the average academic year. If absenteeism differs systematically with athletic participation - we will argue that it does - it clearly has the potential to contribute to explaining the observed heterogeneity in outcomes. ${ }^{3}$

Using a unique dataset from the Seattle Public Schools (SPS), we examine the effect of

\footnotetext{
${ }^{2}$ While the literature's use of "number of instructional days" is a district- or school-specific variable, absenteeism is typically student specific. As such, we anticipate that this will contribute to some students falling behind the pace of instruction and partially foreclose on their ability to absorb new material upon returning. It is in this way that we anticipate that the causal effect of absenteeism may well be larger than that of instructional days. (Of course, this raises an interesting matter of policy, as it is perhaps more efficient to increase attendance than to raise the number of hours or days a teacher is in the classroom.)

${ }^{3}$ Absenteeism has also been directly implicated in determining academic success among university students. For example, Dobkin, Gil and Marion (2010) exploit a discrete change in mandatory attendance for students scoring below the median on midterm exams, and find that a 10-percent increase in attendance increased subsequent exam scores by 0.17 standard deviations. Using variation from randomly determined class times to instrument for attendance, Arulampalam, Naylor and Smith (2012) also find that missing class leads to poorer performance, a relationship that is particularly strong among high-performing students. For additional considerations of absenteeism in post-secondary education see Romer (1993), Durden and Ellis (1995), Marburger (2001), Marburger (2006), Stanca (2006), and Chen and Lin (2008).
} 
active participation in athletics on school attendance. Previous literature (Barron, Ewing and Waddell, 2000) suggests that the main challenge to identifying the effect of athletic participation on attendance is positive selection into athletic participation - those who tend to select into athletics are likely the same as those who tend to select into higher attendance. As such, comparisons of absenteeism rates among athletes and those of the general student body are likely to misidentify the causal effect of athletic participation. In our baseline specifications, then, for years in which we observe a student participating in one or more high school sports, we leverage the only the time-series variation in sport-specific seasons to retrieve an estimate of the causal effect-we include student-by-year fixed effects and identify off of the sport-specific variation in seasons and season length, with each athlete spending some of the school year in season and some not. We thereby avoid the fundamental confounder in identifying the effect of athletic participation on absenteeism. We also absorb unobserved shocks to absenteeism in school-weeks with school-by-year-by-week fixed effects.

In this setting, we show that active participation reduces male athletes' overall absenteeism by 5.2 percent, while net female attendance appears relatively unresponsive. Notably, the effect is primarily explained by a reduction in unexcused absences - arguably, the moremalleable sort of absence - which we interpret as consistent with athletes optimizing around policy-induced incentives. Unexcused absences fall by 10.3 percent at the mean for boys. The relationship is strongest for black male athletes (12.8 percent declines at the mean), among boys in homes with only one parent (11.9 percent), and in lower grades (14.6 percent in grades 9 and 10).

Introducing sport-specific schedules into the analysis then allows us to exploit withinseason variation, and thereby relax the constraint that rates of absenteeism among active athletes are constant within a season of competition. ${ }^{4}$ Doing so, we see even stronger evidence

\footnotetext{
${ }^{4}$ Non-varsity tournaments typically follow varsity schedule. However, non-varsity tournaments are not available.
} 
that students are responding to incentives, as absences fall on game days and rise the day after. This flexibility also reveals a similar pattern among female athletes, with attendance gains on game days offset by declines thereafter of a magnitude that leaves the net effect of athletic participation approximately zero (and therefore insignificant in specifications that ignore the timing of absences around game days).

While the focus of our analysis is on the effect of athletic participation on truancy and absenteeism, before concluding we briefly consider participation's effects on health and grades. On game days, nurse visits fall roughly 15-percent relative to out-of-season boys, which is more than offset by a 33-percent increase the day after. While grades appear unresponsive to the fraction of class days spent in active competition, there is an important heterogeneity within athletes. That is, grades fall slightly with active competition in white and Asian boys while rising with active competition in black and Hispanic boys. The response by white and Asian girls mirrors that of boys, while black and Hispanic girls' academic performance appears unaffected. Consistent with the results on attendance, boys from households without two parents show the largest gains from time spent in active athletic participation.

In Section 2 we provide additional context for the empirical exercise to follow, discussing some of the institutional information and the relevant incentives faced by student athletes. In Section 3 we describe our data and in Section 4 we set up the empirical problem more formally and present results. We offer concluding remarks in Section 5 .

\section{Background}

Reductions in school funding put additional pressure on resources, and parents and others are seeming to be increasingly nervous about potential imbalances in athletic versus academic focus in education. For example, fundamental to the concern of many is that any increase in time allocated to athletics implies offsetting reductions elsewhere. If not a direct substitution, 
the hype and acclaim surrounding athletics may likewise encourage athletes to focus less on academic preparedness, so much so that we could anticipate student athletes sub-optimally investing in non-athletic human capital in favor of sport. Of course, injury and recovery times may well introduce mechanistic relationships between athletic participation and absenteeism.

Alone, these concerns make it tempting anticipate that athletes will exhibit higher levels of truancy and that, if anything, that truancy increases in periods of active participation. Yet, to find such patterns in the data would run counter to a growing literature that documents positive outcomes associated with athletics, which are more consistent with lower rates of absenteeism. Moreover, anticipating tension between academic and athletic pursuits, school districts typically have safeguards in place to protect academic interests. For example, in order to be eligible for competition on a game day, athletes are required to have attended a full day of classes. Athletes can also jeopardize their eligibility by irregular school attendance, whether or not the absences occur on game days, or by failing to maintain minimum academic standards. ${ }^{5}$ While we remain agnostic, as yet, with respect to the effect of athletics on absenteeism, such incentives give reason to anticipate that absenteeism may in fact be lower among athletes. In short, the same "hype" that worries parents and administrators alike, when appropriately governed, introduces a currency of sorts in the policy maker's ability to steward student athletes into classes, as the price of absenteeism is arguably higher for athletes, and particularly higher in-season.

While we take the relationships between athletic participation and longer-run outcomes as given, many of the same challenges to identification in existing literature will exist as here we attempt to identify a role for absenteeism as a possible mechanism. For example, physical activity itself has been linked to improved academic performance which suggests

\footnotetext{
${ }^{5}$ Student athletes in Seattle Public Schools are governed by the Washington Interscholastic Activities Association (WIAA). WIAA requires students to maintain a minimum 2.0 cumulative-grade-point average (GPA), as well as a 2.0 GPA in the classes they are currently enrolled in. For additional information, see www.seattleschools.org/modules/groups/homepagefiles/cms/1583136/File/Forms/Athletics/Handbook.pdf.
} 
that we should anticipate better average outcomes from athletes than non-athletes, even without a direct role for organized sport. In this case, the ideal experiment-hold physical activity constant while varying athletic participation - is largely unachievable. ${ }^{6}$ Given positive selection into athletics, the role of athletics in outcomes could also be confounded by third factors that explain both. For example, Barron, Ewing and Waddell (2000) document that there is indeed a large signaling component to high-school athletic participation-many of the long-run benefits associated with athletics are also consistent with positive sorting of high-ability students into athletics (e.g., educational attainment, employment, wages, holding supervisory positions, receiving piece-rate compensation). ${ }^{7}$ With these concerns in mind, we will identify the effects of athletic participation on absenteeism by exploiting only the differences in the timing and lengths of seasons over the school year for given athletes, and variation in the team-specific dates on which games occur. ${ }^{8}$

\section{Data}

In order to speak to the relationship between athletics and attendance, we acquired restricteduse data from Seattle Public Schools (SPS), inclusive of students' demographics, sportspecific indicators of athletic participation, and daily attendance records. The data span ten traditional SPS high schools over academic years 2008-09 through 2011-12. In order

\footnotetext{
${ }^{6}$ While evidence is mixed, a recent survey in the school-health literature suggests that long-term improvement of academic achievement as a result of more vigorous physical activity is not well substantiated. See (Taras, 2005) for additional discussion.

${ }^{7}$ As not all of the variation in outcomes is explained by selection, there is room for additional human capital having been acquired through participation, which is also consistent with Kuhn and Weinberger (2005), who find that higher wages are partly attributable to the leadership skills developed through athletic participation.

${ }^{8}$ There are examples in the existing literature that consider the effect of sports seasons on attendance by comparing average attendance during the season to average attendance out of season. For example, Laughlin (1978) finds that among 243 high-school wrestlers, attendance is higher during the season. Silliker and Quirk (1997) concludes that among 123 high-school soccer players, attendance at school seemed to be better inseason, but the difference was not significant. In no case that we know of is class-level or day-level variation in attendance exploited, or unobserved student heterogeneity considered.
} 
to identify the effect of athletic participation separately from that due to the effects of other athlete attributes that themselves might directly contribute to attendance, we discard non-athletes and exploit only the exogenous variation in athletic seasons and game days to identify the causal effect of being an athlete on absenteeism. ${ }^{9}$

From among all SPS athletes, we discard all observations for an academic year in which a student participates in multiple sports within the same season (e.g., participation in two SPS defined "winter sports") as such students perhaps face a different treatment intensity or are otherwise different in unobservables. As only 0.79 percent of all SPS athletes participate in two sports within the same season, the cleaner identification purchased here does not come at much of a cost. We also discard all cheerleaders from the analysis, as their participation spans the entirety of all other sport seasons and contribute nothing to our estimate of the effect of being in active competition on attendance. ${ }^{10}$ We also drop any athlete appearing to transfer from one SPS high school to another within a school year.

In the remaining SPS data, daily records of attendance for all student athletes yields a sample of more than 2.5 million student-day observations, or more than 7,000 student athletes. Overall, approximately 35 percent of the boys in SPS and 31 percent of girls in SPS participate in at least one sport during the average academic year in our sample. In Table 1, we stratify demographic and attendance data by gender and, although they will not contribute to the econometric analysis, include statistics for non-athletes for additional context. Within SPS, whites are over-represented in athletics - they account for approximately half of all athletes despite being about one-third of the non-athlete population. In terms of grade level, athletes generally reflect the distribution of the non-athlete population.

\footnotetext{
${ }^{9}$ Non-athletes can be retained in order to better identify other parameters in the model but, without variation in their status (i.e., they are never "active"), they contribute nothing to the estimate of interest. The inclusion of non-athletes would be justified if their patterns of attendance provided at least as good a counterfactual for active athletes' attendance as did inactive athletes. However, there are reasons to believe that this may not be the case (e.g., athletes tending to be better students in other dimensions)

${ }^{10} \mathrm{As}$ is the case for the inclusion of non-athletes, retaining cheerleaders (e.g., to better identify school effects) does not change the reported results.
} 
As indicated in Table 1, athletes and non-athletes differ significantly in their truancy rates. Both male and female athletes are recorded absent for 0.38 school periods per day, on average. With six class periods in the typical school day, this implies that athletes are missing an average of 1.9 class periods per week, or roughly the equivalent of one school day every 3.2 weeks. ${ }^{11}$ Non-athletes are absent roughly 0.64 periods per day, or the equivalent of 3.2 class periods per week, or one day every 1.9 weeks. ${ }^{12}$

In addition to a record of the number of periods absent, our data include whether the absences were "excused" or "unexcused." According to SPS, absences may be excused for reasons pertaining to the health of the student or a family member, as well as for religious holidays, educational activities, a late bus, or a school-imposed suspension. While Washington law explicitly prohibits any other reason from justifying an absence as "excused," parents are given 48 hours following an absence to contact the school and petition to excuse an absence. ${ }^{13}$ Table 1 also reveals two notable differences when absences are tabulated by type. First, despite boys and girls being absent at similar rates overall, the distribution of absence types is markedly different by gender, as girls record approximately 22-percent more excused absences than are recorded for boys. Second, the proportion of excused to unexcused absences is approximately 40-percent higher for athletes than for non-athletes. Also in Table 1, we see the known tendency for athletes' grade point averages to be higher, on average.

Seattle Public Schools control when athletes are considered active, and the types of

\footnotetext{
${ }^{11}$ While beyond our scope, for now, note that any consideration of the "learning cost" of absences should reflect on whether such costs are linear in classes missed. For example, any anticipated nonlinearities in how class absences map into learning deficiencies would imply that missing 0.38 school periods every day may be more costly in terms of learning than missing one school day every 3.2 weeks.

${ }^{12}$ In the two most-recent years, one school implemented a schedule with only five periods per day. Additionally, three schools added an additional study hall period twice a week in a number of the observed academic years, bringing the total possible periods absent to seven on these days. Observations from days with either one fewer or one additional period make up 2.4 percent and 5.3 percent of the data, respectively. Robustness checks demonstrate that our results are not sensitive to the particular class scheduling in these school years. (For example, our results will be robust to the inclusion of fixed effects for school-by-year-by-day-of-week, which cleans up much of the natural variation in absenteeism than may not be attributable to active sport.)

${ }^{13}$ www.seattleschools.org/modules/cms/pages.phtml?pageid=229345\#attendance_matters
} 
activities that can occur in and out of official seasons. This includes the maximum number of matches athletes may participate in (between 10 and 21 per year, depending upon the sport). As shown in Table 1, nearly half of all student-day observations are "in-season," which we refer to as "active" days.

In Table 2, we summarize attendance and participation, by sport, across race and gender. In Panel A, large attendance gaps are evident across the groups, particularly with respect to unexcused absences. Whites and Asians miss, on average, roughly 0.32 periods per day, while blacks and Hispanics miss 0.52. In unexcused absences, though, a gap emerges between whites and Asians, and widens between whites and blacks - white athletes miss only 0.09 unexcused periods per day, while Asian athletes miss about 1.6 times this amount, and black athletes 3.3 times the rate of white athletes. In panel B we see racial compositions varying across sport. Student counts indicate very little participation by some groups within a few sports (e.g., female wrestlers). ${ }^{14}$ It is apparent that the distribution of athletes varies both within and across sports. For example, black students make up the largest racial group in basketball, while swimming (another winter sport) largely attracts white and asian students. Looking within, rather than across columns paints much the same picture-black boys concentrate most heavily in football, basketball and, to a lesser extent, track and field, while the most popular sports for white boys appear to be football, soccer and baseball. The final panels in Table 2 show that time spent in-season is approximately equal across race and gender, and that the proportion of athletes participating in one, two or three sports per year are similar across columns.

In Table 3, we provide a simple comparison of average attendance rates across "active" and "inactive" athletes by sport. The results show no clear picture of the effect of being in active competition on attendance as average attendance rates among athletes in some sports appears to go up during the sport's season while declining for others. One possible

\footnotetext{
${ }^{14}$ To protect the privacy of students, results calculated from data on 10 or fewer students are suppressed.
} 
explanation for this is the fact that these attendance statistics fail to account for general patterns of attendance over the school year, leaving spring sports appearing to have a negative affect on attendance, since attendance in the spring is relatively poor, generally, regardless of sports participation or in-season status.

To summarize the general patterns in attendance, we plot the average daily periods absent for active and inactive athletes, and non-athletes over the academic year in Figure $1 .{ }^{15}$ It is clear that for unexcused absences in particular, there is an upward trend through the academic year. What is interesting, however, is that while the unexcused absences of inactive athletes follow the general upward trend in the general student population in the latter part of the year, the unexcused absences of active athletes fail to rise, until much later in the year when many athletes are still "active" yet are no longer competing as the state championship tournament concludes.

\section{Empirics}

\subsection{The effect of in-season status on absenteeism}

To begin, we simply consider how being in active competition changes daily average attendance of athletes. Using the panel of daily attendance records for all SPS students in the sample years (2008-09 through 2011-12) in which they participated in at least one high-school sport, we estimate the the model,

$$
\text { PeriodsAbsent }_{i, s, d}=\alpha+\beta \text { Active }_{i, s, d}+\epsilon_{i, s, d}
$$

where PeriodsAbsent $_{i, s, d}$ is the number of school periods individual $i$ at school $s$ is absent on day $d$, and is determined by $i$ 's participation status, Active $e_{i, s, d}$, which equals one if student

\footnotetext{
${ }^{15}$ Note that different students are contributing to the athlete plots in different time periods, while the non-athlete plot is the same set of students throughout the school year.
} 
$i$ is in-season on day $d$. In all specifications, standard-error estimates correct for possible clustering at the school level. ${ }^{16}$ Given differences in absenteeism and possible differences in the intensity of treatment across genders, we estimate (1) separately for boys and girls. Of course, if active athletics participation decreases absenteeism, $\hat{\beta}$ will be negative.

The results in column 1 of Table 4 imply that active athletes exhibit lower rates of absenteeism on average. The number of periods boys are absent declines with active participation by approximately .027 per day, or 7 percent of the absence rate exhibited by inactive athletes (.39 classes daily). Active girls are absent .022 fewer classes per day, or 5.7 percent of the mean out-of-season absence rate (also .39 classes). The size and statistical significance of the estimates are modest, indicating with the confidence interval around the point estimate on the relationship between girls' sports participation and their school attendance spanning zero.

In several dimensions, even though the simple model of (1) cannot be explained by athlete selection, it fails to account for athletes selecting systematically into seasons (i.e., sports), which may correlate with other unobservable student attributes that drive attendance. For example, if students who have more active days in a given year are more industrious or more competitive, and also have lower rates of absenteeism through the year, the point estimate in column 1 will be biased downward. If school attendance in the spring term tended to be lower where sports participation was higher (note that this is the case), this variation would

\footnotetext{
${ }^{16}$ With few clusters (e.g., we have ten schools), the asymptotic approximation of the autocorrelation within clusters may not be valid. We have conducted sensitivity analysis with respect to estimated standard errors, correcting for possible clustering at the school-year, and at the school-week level. Of the options, correcting for clustering at the school-level yields the largest standard-error estimates, which we choose to present. This is consistent with Baum, Nichols and Schaffer (2011) who note that "with nested levels of clustering, clusters should be chosen at the most aggregate level ... to allow for correlations among individuals at that level," and with Cameron and Miller (forthcoming), who argue that "the consensus is to be conservative and avoid bias and use bigger and more aggregate clusters when possible, up to and including the point at which there is concern about having too few clusters." In Appendix Table A2 we demonstrate the sensitivity of standard-error estimates to various assumptions on the pattern of clustering. T-tests are conducted using $G-1=9$ degrees of freedom when correcting for clustering at the school level. We also provide confidence intervals for the main results following the "few clusters" approach of Ibragimov and Müller (2010) and Ibragimov and Müller (2013).
} 
also be potentially problematic. Likewise, school-level factors, more broadly, may correlate with attendance and average season lengths at the school.

To account for such potential confounders, we re-estimate (1) as,

$$
\text { PeriodsAbsent }_{i, s, d}=\alpha+\beta \text { Active }_{i, s, d}+\lambda_{i, y}+\tau_{s, w}+u_{i, s, d}
$$

with the addition of student-by-year fixed effects, $\lambda_{i, y}$, and school-by-year-by-week fixed effects, $\tau_{s, w}$. Thus, in columns 2 and 3 of Table 4, we identify the effect of being in active competition on absenteeism by leveraging two sources of variation separately: the day-by-day variation in in-season status for a given student, and, the student-by-student variation in in-season status within a given school-week. In column 4 we report point estimates from our preferred specification, identifying off of within-student variation in the timing of their active season while also absorbing school-week specific shocks into the error structure. While point estimates do move across columns, the overall story is consistently that attendance improves with active competition. From our fully-specified model, estimates imply that boys' absences fall with active athletic participation - being in-season reduces the number of periods absent by 5.2 percent relative to that seen out-of-season, on average. Although point estimates suggest that absences also decline among girls (3.3 percent), one should hesitate drawing such a conclusion as the confidence interval also includes zero.

\subsection{Are patterns of unexcused and excused absences different?}

Before we consider the potential for heterogeneous effects, it will be instructive to consider the distinctions between absences designated "excused" versus those designated "unexcused." In particular, by separately identifying the effect of active competition on the type of absence has the potential to separate competing patterns of behavior. For example, a decline in un-

excused absences would be consistent with athletes substituting away from oversleeping or 
leisure activities crowding out classes - examples of the sort of behavior that leads to unexcused absences - while excused absences should move differently, if not at all. ${ }^{17}$ We hesitate to think of this as a proper falsification exercise, as we can easily think of mechanisms that would move excused absences systematically with sport activity. For example, offsetting increases in excused absences would be consistent with students or parents investing additional resources in having given absences excused while the student is actively participating. As absences may be "excused" for reasons pertaining to the health of the student, we likewise might anticipate increases in excused absences among sports particularly susceptible to injury. (We will discuss this further when we consider whether there is a systematic pattern of nurse visits around active competition.)

In Table 5, we report the estimated effect of being active on excused and unexcused absences, adopting the fully-specific model in (2). Doing so clearly points to the patterns of absenteeism among boy athletes being driven by their "unexcused" behavior-unexcused absences decline 10.3 percent when athletes are active, though excused absences decline only insignificantly (1.3 percent). The small negative effect of being active on excused absences should not be ignored, however, as it is by this that we learn that the decline in unexcused absences cannot be explained by parents investing in having given absences excused when their children are actively competing. Were this the case, which we could not rule out $a$ priori, that the point estimate in column 2 would be positive.

As is the case in the restricted model reported in Table 4, the patterns of absences around girls' active competitions again appear modest when separated by whether the absence was excused or not. However, we can still rule out that parents are investing additional resources in having given absences excused when their girls are actively competing. Although insignificant, interpreting point estimates directly implies that unexcused and excused absences

\footnotetext{
${ }^{17}$ Sanctioned tournaments that directly conflict with classes would, we imagine, increase excused absences. However, we see no evidence that any scheduled tournaments conflict with classes.
} 
decline among girls by 3.3 percent.

\subsection{Heterogeneity}

\subsubsection{Race}

Assuming that the effect of active participation on absenteeism is constant across race seems overly restrictive in light of significant race differences in both school attendance and sports participation. We therefore stratify the earlier estimates by race, which we present in Table 6. Among boys, doing so reveals that the effect of being in active competition on unexcused absences is strongest among black and Hispanic boys, who exhibit a 12.8-percent decline in unexcused absences relative to their average out-of-season attendance rates (which are high relative to white and Asian boys). The decline in white and Asian absenteeism is less than half this size (relative to their mean) and statistically insignificant at conventional levels. As in earlier specifications, excused absences do not increase in-season among any race/gender group, which we continue to interpret as ruling out that parents are more inclined to have given absences excused when their children are actively competition. ${ }^{18}$

\subsubsection{Family structure}

In Table 7 we stratify by a measure of family structure - whether the student is recorded as living with both parents, or "not with both parents," which includes those in foster care, living with grandparents, or, as is predominantly the case, with one parent. There is a large body of work highlighting the association between divorce and children's long-run outcomes. As such, we think that considering the role of family structure in how athletics explains

\footnotetext{
${ }^{18}$ Going one step further, any declines in excused absences would be consistent with improved health of the student or family, fewer conflicting educational activities or late buses, or a decline in school-imposed suspensions during active seasons.
} 
outcomes is an important aspect for policy makers to consider. ${ }^{19}$

While power is somewhat limited, there is a noteworthy robustness to the black and Hispanic result above; Table 7 suggests that this is capturing a single-parent effect, of a sort. Note, first, that the stratification by family structure reveals that average absenteeism is higher among single-parent families in all race/gender cells. Unexcused absences are highest among black and Hispanic boys from single-parent homes (.39), while excused absences are highest among black and Hispanic girls from single-parent homes (.32).

Among boys (Panel A), the effect of being in active competition on unexcused absences is seemingly strongest among black and Hispanic boys from single-parent homes-declines in unexcused absences are 12.4 percent relative to their mean out-of-season attendance rates. The effect among black and Hispanic boys of two-parent households is also large -9 percent relative to the mean-but fails to exclude zero from the confidence interval. In Panel B we see that girls' unexcused absences are of similar magnitude, regardless of family structure, though precision and percentage-impact are greater among girls in two-parent households. In no case does stratifying by family structure reveal significant relationships between athletic participation and excused absences, although the impact for black and Hispanic students generally exceeds that of whites and Asians.

\subsubsection{Grade level}

The incentives to please coaches or compete for playing time may change throughout athletes' high-school careers, making any grade-level heterogeneity an interesting distinction. In Table

\footnotetext{
${ }^{19}$ Using the National Longitudinal Survey of Youth, Antecol and Bedard (2007) "find that an additional five years with the biological father decreases the probability of smoking, drinking, engaging in sexual activity, marijuana use, and conviction." Exploiting variation in the divorce rate generated by changes in states' unilateral divorce laws, Gruber (2004) demonstrates that those adults exposed to unilateral divorce as children in the decade after the law change obtained less total education. This same identifying variation leads Cáceres-Delpiano and Giolito (2012) to conclude that individuals who were children at the time of the reforms exhibited higher rates of violent crime arrests as adults. Both Antecol and Bedard (2007) and Cáceres-Delpiano and Giolito (2012) cite reduced supervision and adult interaction as possible mechanisms. We believe this explanation to be particularly relevant for athletes as coaches have the potential to serve as de facto surrogates to active athletes, providing adult supervision and role modeling otherwise absent.
} 
8, we estimate the effect of being in active competition on excused and unexcused absences stratifying by upperclassman and underclassman status, and again by gender. Across both boys and girls, active engagement in athletics predicts larger declines in absenteeism in earlier grade levels (i.e., grades nine and ten). This is particularly so among boys, where absenteeism rates are some 14.6-percent lower at the mean, a reduction of .7 class periods in a five-day school week. Among upperclassmen, the estimated effect remains statistically significant, but drops in size to 6.1-percent of the mean absenteeism rate. Again, in boys, excused absences do not appear to be responsive to active sports participation, and the negative point estimates again suggest that there is no measurable substitution across unexcused and excused absences. Excused absences do fall among girls in lower grade levels, although there is also less heterogeneity across active and inactive athletes.

\subsection{Are there game-day effects on absenteeism?}

According to the Washington Interscholastic Activities Association (WIAA), athlete attendance is monitored and eligibility is jeopardized by poor attendance. However, it is notable that athletes are required to attend a full day of school on the day of any sport competition in order to be eligible for competition. As such, to the extent students are responding to incentives, we might expect more than simple level shifts in attendance for periods of active participation.

To our data, we add nearly 8,500 tournament events - school-by-sport-specific dates on which competition occurred within SPS. Schedule data for all sports were collected from daily online historical records in the Seattle Times, internet records databases, and from high-school coaches. ${ }^{20}$ We believe we have nearly full coverage over the four years, though we suspect some missing dates for the wrestling tournaments and gymnastics meets occurring in the first two years.

\footnotetext{
${ }^{20}$ See www.athletic.net, www.maxpreps.com, and www.nwcaonline.com.
} 
In the models of Table 9, we allow student $i$ 's absenteeism to vary differently on game days, and on the calendar days immediately before and after a game. ${ }^{21}$ We adopt our preferred specification from above, but, as sports can tend to follow somewhat regular schedules (e.g., football tending to play games on Fridays), we report specifications with and without dayof-week fixed effects.

Allowing for this flexibility proves important to fitting the data, and reveals an interesting pattern that is consistent with students optimizing around the incentives they face. For boys, the pattern in unexcused absences is clearly systematic around tournament dates, with the overall decline in absences documented above seemingly driven by general declines in absenteeism, but particularly large declines in absenteeism on game days, with an offsetting increase on days following tournaments, where active athletes are apparently not different from inactive (i.e., out-of-season) athletes. This pattern is consistent with a strong behavioral response to the policy, but with an offsetting effect - athletes make up for their increased attendance leading up to game days with post-game-day retreats, of a sort. This pattern is even more evident in excused absences. While the earlier results (see Table 5) reveal no net difference in excused absences between in-season and out-of-season boys, allowing for gameday effects in Table 9 uncovers an underlying pattern of declining absences leading into game days (although point estimates are insignificant) and a large and significant increase in excused absences on days that follow game days. Using the point estimates from the models without day-of-week fixed effects, relative to the average active boy on days not surrounding a tournament, active boys experience only slightly lower absenteeism rates the day before a game. However, the effect is more than doubled on game days, reducing truancy by 21percent relative to inactive athletes. This is followed by a rise in truancy on the day after a game, even accounting for the overall reduction while in-season. Excused absences also

\footnotetext{
${ }^{21}$ For example, only Thursday football games are identifying the effect on post-game-day absenteeism for football players. Practice schedules are not available, but we imagine them contributing to any differences between active and inactive absences that are apparent beyond the plus/minus one-day margin.
} 
increase on the day after a game - the day after a game, excused absences are 13.6-percent higher than we see in active boys on days not surrounding a game. While this is consistent with parents investing additional resources in having absences excused, our prior would be for such practice to be demonstrated leading up to game days, or on game days, where marginal absences are more likely to trigger ineligibility. Thus, we anticipate that part of this pattern may be explained by injury and or recovery times, which we consider below.

Among girls, recall that we found no significant differences in either unexcused or excused absences overall. However, allowing for game-day effects in the patterns of absences likewise points to significant reductions in absences on game days followed by significant increases in absences on days that follow game days. Relative to the average inactive girl, active girls exhibit similar absenteeism rates the day before a game, but 9.1-percent lower truancy rates on game days. On days following games, they exhibit 11.6-percent higher unexcusedabsenteeism rates when compared to active girls on game days or the day prior. Excused absences decrease 13.7 percent on game days, but again rise the day after a game.

While somewhat cumbersome given that tournaments for some sports fall disproportionately on particular days of the week (e.g., a majority of football games occur on Fridays, and cross-country invitational meets on Saturdays), sport-specific estimates are provided in tables 10 and 11. Across all sports, the model suggests that football players are potentially the most sensitive to game-day effects. On days prior to games they are 38.8-percent less likely to be absent than are inactive male athletes, 44.1-percent less likely on game days, but 54.1-percent more likely to be absent on days following a game. ${ }^{22}$ Other sports in which absenteeism is seemingly quite responsive to game days include boys' basketball (8.8-percent decrease, 43.5-percent decrease, and 7.7-percent increase) and girls' basketball (21.7-percent decrease, 61.7-percent decrease, and 10.8-percent increase). Two sports-cross country and

\footnotetext{
${ }^{22}$ Relative to the off-season rates of absenteeism specifically among football players (.34), these numbers are also quite large, at $-19.4,-22.1$, and 27.1.
} 
golf, which both attract mainly white and Asian students - seemingly having unexcused absences increase with active participation.

\subsection{Effects on health}

There is twofold interest in considering nurse visits by athletes around game days. First, competition-related injuries present another possible mechanism through which attendance and learning may be crowded out. Second, to the extent that such visits represent costly outcomes to high-school athletics, we have direct interest in quantifying such a mechanism. Here, we consider daily records of athletes' visits to school-based health centers located in each of the high schools in our sample. From the records, we use only those visits seemingly related to a physical-health complaint or injury. ${ }^{23}$ While we do not observe injured students who are absent from school, elevated numbers of nurse visits following tournaments would nonetheless suggest either a substitution from other days or an increase in injuries suffered on game days. Of course, given that game-day injuries lead to absences on subsequent days, we anticipate that our estimates will understate the true effects of active sports participation on injuries. ${ }^{24}$

In the first two columns of Table 12 we present results from linear-probability models

\footnotetext{
${ }^{23}$ There are 13 categories students can be referred to the nurse for: Physical health complaint, injury, medication, social/emotional, SPED assess, health screen, nursing treatment, immunization, possible abuse, AOD (alcohol/drugs), disability related services (under Section 504 of the Rehabilitation Act), Student Intervention Team (SIT) Assessment, and barriers to learning assessment follow-up (SDQ).

${ }^{24}$ Traditionally, recognition of the dangers that athletics pose to participants has focused on injuries with localized effects and symptoms directly associated with the injured body part, such as sprains, dislocations and muscle contusions. Recent research on sports injuries indicates that mild traumatic brain injuries (also known as concussions, or MTBIs for short) may be more prevalent than previously thought with the potential for serious medium and longterm effects not readily apparent (McCrory, Meeuwisse, Johnston, Dvorak, Aubry, Molloy and Cantu (2009)). In the 2005/06 academic year, an estimated 136,000 sports-related concussions occurred in U.S. high schools, with nearly four out five occurring during competition (Gessel, Fields, Collins, Dick and Comstock (2007)). Previously concussed students returning to school may experience an aggravation of symptoms by the conditions found in the classroom, and seek medical at the school nurse as the brain works to recover. McAvoy (2012) notes that recovery typically occurs over a one to three week period. It would not be surprising for students to feel well enough to return to school, only to then visit the nurse with MTBI-related headaches, nausea or dizziness.
} 
estimating the effect of active sports participation (including game-day effects) on the probability of visiting a school nurse with a injury or physical health complaint. ${ }^{25}$ As before, the models are estimated with and without day-of-week fixed effects, again, not revealing sensitivity to their inclusion.

From this analysis, several interesting results emerge. First, though point estimates are positive, active athletes do not visit the school nurse at different rates overall. Second, among female athletes, we note that there is very little movement in nurse visits around game days. Third, despite higher rates of attendance on game days, boys are somewhat less likely to visit the school nurse on the day of a competition - some 1.7-percent less likely than the average inactive boy athlete - possibly reflecting that athletes may "tough it out" for a chance to play. This pattern is somewhat worrying, however, as this may reflect suboptimal investments in medical care among athletes around competition.

Finally, on days following tournaments, we identify a large spike in active male athletes visiting the school nurse with injuries or physical complaints. This effect is large and statistically significant - a 37.5-percent increase relative to mean out-of-season rates - despite the fact that fewer athletes are present at school on the days that follow a tournament.

\subsection{Academic performance}

We next turn to an analysis of the effects of active participation on student achievement, leveraging student-by-class level administrative transcript data. With the potential to consider within-class variation in performance, we generally have six observations per semester for each athlete - for each we have a course title, subject code, and final letter grades. For our purpose, we transform letter grades into a standard 4.0 scale, and create a semester-level measure of active participation for each athlete using the sport-specific schedules considered

\footnotetext{
${ }^{25}$ This is not conditioned on being present at school. Yet, note that a substantial number of individuals have nurse visits on days in which they miss all periods. We imagine, although we have yet to confirm, that students may show up for classes but subsequently report to the nurse before the first bell.
} 
above. That is, we regress athlete $i$ 's performance in class $c$ on the proportion of semester $t$ that athlete spent in season,

$$
\text { Grade }_{i, c, t}=\alpha+\gamma \text { Prop. Semester Active }{ }_{i, t}+\lambda_{i}+\eta_{g}+\sigma_{s, c, t}+u_{i, c, t},
$$

where $\sigma_{s, c, t}$ is a set of school-by-course-by-semester-by-school-year fixed effects. ${ }^{26}$ Relative to attendance, grades represent an infrequently observed outcome of sports participation, being observed only twice per year. We therefore relax the assumption of individual-by-year fixed effects, which utilizes only variation in a student's active participation occurring between the first and second semesters, with the inclusion of individual and grade fixed effects $\left(\lambda_{i}\right.$ and $\eta_{g}$, respectively). Estimated standard errors again allow clustering at the school level.

In Table 13 we provide a table of results similar to that for absenteeism, with and without the extensive sets of fixed effect. While initial specifications suggest some systematic variation in academic performances with differences in the intensity of active participation, once we account for unobserved heterogeneity specific to students and to semester-specific courses within schools (in column 4) the point estimates are small, and statistically insignificant. ${ }^{27}$

In Table 14, we stratify by both gender and race, which reveals an important difference in how grades move with active participation. In particular, in boys, point estimates suggest that performance among black and Hispanic athletes improves with active participation and the effect is statistically significant. White and Asian athletes appear to suffer slight declines, though the estimate is not statistically significant. The same asymmetry is true among female athletes, with white and Asian athletes' grades declining and black and Hispanic's rising,

\footnotetext{
${ }^{26}$ By course, we mean to imply a particular subject and course code (e.g., Geometry 101) rather than a particular section of Geometry 101. Schools may teach concurrent sections of the same course within a semester.

${ }^{27}$ Given the discrete nature of letter grades, a point estimate of 0.095 cannot represent a 0.095 average increase across all courses in a semester which is spent entirely in-season. Rather, accounting for such an effect arising from across six classes, the effect is equivalent to a student experiencing roughly a 0.3 point increase in two classes (e.g., going from B to B+) or a 0.6 point increase in one class (e.g., one grade being changed from B to A-).
} 
but both effects are small relative to the effect for black and Hispanic boys, and statistically significant at the 10-percent level only for white and Asian girls.

In Table 15 we again stratify by a measure of family structure - whether the student is recorded as living with both parents, or "not with both parents," which includes those in foster care, living with grandparents, or, as is predominantly the case, with one parent. Doing so, suggests that it is black and Hispanic boys who do not live with both parents that drive the relationship between active participation and improvements in academic outcomes. Moreover, the magnitude of the point estimate is not inconsequential, suggesting that black and Hispanic boys spending most of the semester active could improve by nearly 0.3 in two classes (e.g., the difference between a B and a B+). Stratifying by family structure also reveals that there is declining performance with active participation among white boys living with two parents. The magnitude of this decline is small, however, relative to the gains by black and Hispanic athletes, and marginally statistically significant.

Among girls, the academic performance of those living with both parents appears unresponsive to the athletic calendar, whether pooled or stratified by race. The net effect of greater active sports participation for girls not living with both parents is negative, which appears to be driven by declines by white and Asian girls.

\section{Conclusion}

Using data on daily student-level records of attendance, we find that active athletic participation reduces absenteeism, with truancy reductions as the primary source of benefit. We find the effects to be particularly strong for black and Hispanic students, and athletes living in single-parent households. Despite the overall reductions, there are partially offsetting increases in absenteeism following game days - allowing for sport-specific effects, relative to inactive athletes we find as large as a 28-percent increase in the propensity for football 
players to record unexcused absences on days following a game. While the truancy pattern increases our confidence in having retrieved estimates of the causal effect of participation on absenteeism, at the same time we see the partial undoing of the attendance gains leading up to game days as an area of immediate concern. Also troubling are increases in visits to school nurses among male athletes on days following competition (despite higher absenteeism). Likewise, lower utilization on the day of a tournament suggests under-provision of health services that is equally troubling. Students' transcripts also suggest that the truancy response to active participation may show up in academic gains - the longer is athlete's length of season, the higher is academic performance. The magnitudes are not strikingly large, however, which leaves room for future research in this area.

\section{References}

Antecol, Heather and Kelly Bedard, "Does single parenthood increase the probability of teenage promiscuity, substance use, and crime?," Journal of Population Economics, 2007, 20 (1), 55-71.

Arulampalam, Wiji, Robin A Naylor, and Jeremy Smith, "Am I missing something? The effects of absence from class on student performance," Economics of Education Review, 2012, 31 (4), 363-375.

Barron, John M, Bradley T Ewing, and Glen R Waddell, "The effects of high school athletic participation on education and labor market outcomes," Review of Economics and Statistics, 2000, 82 (3), 409-421.

Baum, Christopher F., Austin Nichols, and Mark E. Schaffer, "Evaluating one-way and two-way cluster-robust covariance matrix estimates," July 2011.

Cáceres-Delpiano, Julio and Eugenio Giolito, "The impact of unilateral divorce on crime," Journal of Labor Economics, 2012, 30 (1), 215-248.

Cameron, A. Colin and Douglas L. Miller, "A Practitioner's Guide to Cluster-Robust Inference," Journal of Human Resources, October 2013 forthcoming.

Chen, Jennjou and Tsui-Fang Lin, "Class attendance and exam performance: A randomized experiment," The Journal of Economic Education, 2008, 39 (3), 213-227. 
Dobkin, Carlos, Ricard Gil, and Justin Marion, "Skipping class in college and exam performance: Evidence from a regression discontinuity classroom experiment," Economics of Education Review, 2010, 29 (4), 566-575.

Durden, Garey C and Larry V Ellis, "The effects of attendance on student learning in principles of economics," The American Economic Review, 1995, pp. 343-346.

Eide, Eric R and Nick Ronan, "Is participation in high school athletics an investment or a consumption good? Evidence from high school and beyond," Economics of Education Review, 2001, 20 (5), 431-442.

Eren, Ozkan and Daniel Millimet, "Time to learn? The organizational structure of schools and student achievement," Empirical Economics, May 2007, 32 (2), 301-332.

Gessel, Luke M, Sarah K Fields, Christy L Collins, Randall W Dick, and R Dawn Comstock, "Concussions among United States high school and collegiate athletes," Journal of athletic training, 2007, 42 (4), 495.

Gruber, Jonathan, "Is making divorce easier bad for children? The long-run implications of unilateral divorce," Journal of Labor Economics, 2004, 22 (4), 799-833.

Hansen, Benjamin, "School Year Length and Student Performance: Quasi Experimental Evidence," 2011.

Ibragimov, Rustam and Ulrich K Müller, "t-Statistic based correlation and heterogeneity robust inference," Journal of Business 83 Economic Statistics, 2010, 28 (4), 453-468.

_ and Ulrich K. Müller, "Inference with Few Heterogeneous Clusters," July 2013.

Kuhn, Peter and Catherine Weinberger, "Leadership Skills and Wages," Journal of Labor Economics, 2005, 23 (3), 395-436.

Laughlin, Neil T, "Athletic participation and the grade point average, absences, cuts, and disciplinary referrals of high school athletes.," International Journal of Sport Psychology, 1978.

Lavy, Victor, "Do Differences in Schools' Instruction Time Explain International Achievement Gaps? Evidence from Developed and Developing Countries," 2012.

Lee, Jong-Wha and Robert J Barro, "Schooling quality in a cross-section of countries," Economica, 2001, 68 (272), 465-488.

Lipscomb, Stephen, "Secondary school extracurricular involvement and academic achievement: A fixed effects approach," Economics of Education Review, 2007, 26 (4), 463-472.

Marburger, Daniel R, "Absenteeism and undergraduate exam performance," The Journal of Economic Education, 2001, 32 (2), 99-109. 
_ , "Does mandatory attendance improve student performance?," The Journal of Economic Education, 2006, 37 (2), 148-155.

Marcotte, Dave E., "Schooling and Test Scores: A Mother-Natural Experiment," Economics of Education Review, 2007, 26 (3), 629-640.

Marcotte, Dave E and Benjamin Hansen, "Time For School?," Education Next, 2010, $10(1), 53-9$.

Marcotte, Dave E. and Steven W. Hemelt, "Unscheduled School Closings and Student Performance," Education Finance and Policy, 2008, 3 (3), 316-338.

McAvoy, Karen, "Return to Learning: Going Back to School Following a Concussion," Communique, 2012, 40 (6).

McCrory, Paul, Willem Meeuwisse, Karen Johnston, Jiri Dvorak, Mark Aubry, Mick Molloy, and Robert Cantu, "Consensus Statement on Concussion in Sport 3rd International Conference on Concussion in Sport Held in Zurich, November 2008," Clinical Journal of Sports Medicine, 2009, 19 (3), 185-200.

Persico, Nicola, Andrew Postlewaite, and Dan Silverman, "The Effect of Adolescent Experience on Labor Market Outcomes: The Case of Height," Journal of Political Economy, 2004, 112 (5), 1019-1053.

Pfeifer, Christian and Thomas Cornelißen, "The impact of participation in sports on educational attainment - New evidence from Germany," Economics of Education Review, 2010, 29 (1), 94-103.

Pischke, Jörn-Steffen, "The Impact of Length of the School Year on Student Performance and Earnings: Evidence From the German Short School Years," The Economic Journal, 2007, 117 (523), 1216-1242.

Rees, Daniel I and Joseph J Sabia, "Sports participation and academic performance: Evidence from the National Longitudinal Study of Adolescent Health," Economics of Education Review, 2010, 29 (5), 751-759.

Rivkin, Steven G and Jeffrey C Schiman, "Instruction Time, Classroom Quality, and Academic Achievement," Technical Report, National Bureau of Economic Research 2013.

Romer, David, "Do students go to class? Should they?," The Journal of Economic Perspectives, 1993, 7 (3), 167-174.

Silliker, S Alan and Jeffrey T Quirk, "The effect of extracurricular activity participation on the academic performance of male and female high school students.," School Counselor, 1997, 44 (4), 288-93. 
Stanca, Luca, "The effects of attendance on academic performance: Panel data evidence for introductory microeconomics," The Journal of Economic Education, 2006, 37 (3), 251-266.

Stevenson, Betsey, "Beyond the classroom: Using Title IX to measure the return to high school sports," The Review of Economics and Statistics, 2010, 92 (2), 284-301.

Taras, Howard, "Physical activity and student performance at school," Journal of School Health, 2005, 75 (6), 214-218. 
Table 1

Summary statistics for athletes and non-athletes

\begin{tabular}{|c|c|c|c|c|c|c|}
\hline & \multicolumn{3}{|c|}{ Boys } & \multicolumn{3}{|c|}{ Girls } \\
\hline & Athletes & Non-athletes & All & Athletes & Non-athletes & All \\
\hline Students & 3,941 & 7,360 & 11,301 & 3,217 & 7,290 & 10,507 \\
\hline Student-years & 7,907 & 13,344 & 21,251 & 6,453 & 13,395 & 19,848 \\
\hline Student-days & $1,382,011$ & $2,258,556$ & $3,640,567$ & $1,132,704$ & $2,278,796$ & $3,411,500$ \\
\hline White & .49 & .36 & .41 & .52 & .31 & .38 \\
\hline Asian & .20 & .26 & .24 & .24 & .26 & .25 \\
\hline Black & .21 & .22 & .22 & .14 & .28 & .23 \\
\hline Other & .11 & .17 & .15 & .11 & .16 & .14 \\
\hline Grade 9 & .28 & .32 & .31 & .28 & .29 & .29 \\
\hline Grade10 & .26 & .24 & .25 & .28 & .24 & .26 \\
\hline Grade11 & .24 & .21 & .22 & .24 & .22 & .23 \\
\hline Grade12 & .22 & .23 & .23 & .20 & .24 & .23 \\
\hline Both Parents & .69 & .54 & .60 & .70 & .53 & .58 \\
\hline Periods Absent per Day & .38 & .65 & .55 & .38 & .64 & .56 \\
\hline Periods Excused & .22 & .28 & .26 & .27 & .33 & .31 \\
\hline Periods Unexcused & .16 & .38 & .29 & .11 & .31 & .25 \\
\hline Daily $\operatorname{Pr}[$ Nurse Visit] & .0013 & .0016 & .0015 & .0014 & .0023 & .0020 \\
\hline Semester GPA & 3.01 & 2.40 & 2.63 & 3.37 & 2.73 & 2.94 \\
\hline
\end{tabular}


Table 2

Summary statistics for athletes by race, gender, and sport

\begin{tabular}{|c|c|c|c|c|c|c|c|c|}
\hline & \multicolumn{4}{|c|}{ Boys } & \multicolumn{4}{|c|}{ Girls } \\
\hline & White & Asian & Black & Other & White & Asian & Black & Other \\
\hline Panel A: Absenteeism & tatistics & across 1 & ace and & gender & & & & \\
\hline Periods Absent & .32 & .30 & .52 & .51 & .35 & .32 & .53 & .49 \\
\hline Periods Excused & .23 & .17 & .24 & .25 & .28 & .21 & .30 & .31 \\
\hline Periods Unexcused & .09 & .14 & .29 & .25 & .07 & .11 & .23 & .18 \\
\hline
\end{tabular}

Panel B: Athlete-by-year counts by race, gender and sport

$\begin{array}{lcccccccc}\text { Baseball } & 693 & 150 & 156 & 98 & . & . & . \\ \text { Basketball } & 378 & 130 & 622 & 83 & 288 & 90 & 325 & 119 \\ \text { Cross Country } & 658 & 163 & 71 & 76 & 488 & 136 & 63 & 48 \\ \text { Football } & 847 & 289 & 647 & 258 & . & . & . & . \\ \text { Golf } & 323 & 64 & - & - & 89 & 59 & - & - \\ \text { Gymnastics } & - & - & - & - & 287 & 110 & 36 & 42 \\ \text { Soccer } & 724 & 170 & 268 & 260 & 805 & 171 & 114 & 125 \\ \text { Softball } & - & . & . & . & 385 & 180 & 124 & 115 \\ \text { Swimming } & 495 & 221 & 30 & 49 & 615 & 263 & 19 & 87 \\ \text { Tennis } & 333 & 456 & 29 & 59 & 482 & 511 & 89 & 96 \\ \text { Track } & 634 & 258 & 389 & 121 & 510 & 137 & 268 & 100 \\ \text { Volleyball } & - & \cdot & - & - & 505 & 297 & 170 & 142 \\ \text { Wrestling } & 326 & 203 & 107 & 100 & 34 & 36 & - & -\end{array}$

Panel C: Percent of school year spent in-season

$\begin{array}{lllllllllll}\text { In-season } & .50 & .48 & .51 & .48 & .48 & .46 & .48 & .48\end{array}$

Panel D: Percent participating in 1, 2 or 3 sports per year

\begin{tabular}{lllllllll}
1 sport & .64 & .71 & .66 & .70 & .70 & .73 & .71 & .72 \\
2 sports & .31 & .23 & .27 & .25 & .25 & .24 & .23 & .23 \\
3 sports & .05 & .06 & .08 & .05 & .05 & .04 & .05 & .06 \\
& & & & & & & & \\
\hline
\end{tabular}


Table 3

Athletes' in-season and out-of-season absences, by sport

\begin{tabular}{|c|c|c|c|c|}
\hline & \multicolumn{2}{|c|}{ Boys } & \multicolumn{2}{|c|}{ Girls } \\
\hline & Out-of-season & In-season & Out-of-season & In-season \\
\hline \multicolumn{5}{|c|}{ Panel A: Absent Periods - Unexcused } \\
\hline \multicolumn{5}{|l|}{ Fall Sports } \\
\hline Cross Country & 0.09 & 0.04 & 0.10 & 0.04 \\
\hline Football & 0.34 & 0.16 & & \\
\hline Golf & 0.10 & 0.05 & 0.09 & 0.11 \\
\hline Volleyball & & & 0.17 & 0.08 \\
\hline \multicolumn{5}{|l|}{ Winter Sports } \\
\hline Basketball & 0.25 & 0.19 & 0.24 & 0.18 \\
\hline Gymnastics & & & 0.08 & 0.07 \\
\hline Swimming & 0.08 & 0.06 & 0.08 & 0.05 \\
\hline Wrestling & 0.21 & 0.17 & 0.21 & 0.20 \\
\hline \multicolumn{5}{|l|}{ Spring Sports } \\
\hline Baseball & 0.11 & 0.15 & & \\
\hline Soccer & 0.14 & 0.18 & 0.12 & 0.06 \\
\hline Softball & & & 0.14 & 0.17 \\
\hline Tennis & 0.08 & 0.08 & 0.06 & 0.09 \\
\hline Track & 0.11 & 0.16 & 0.12 & 0.16 \\
\hline \multicolumn{5}{|c|}{ Panel B: Absent Periods - Excused } \\
\hline \multicolumn{5}{|l|}{ Fall Sports } \\
\hline Cross Country & 0.21 & 0.16 & 0.28 & 0.21 \\
\hline Football & 0.28 & 0.24 & & \\
\hline Golf & 0.25 & 0.21 & 0.22 & 0.28 \\
\hline Volleyball & & & 0.33 & 0.23 \\
\hline \multicolumn{5}{|l|}{ Winter Sports } \\
\hline Basketball & 0.24 & 0.24 & 0.30 & 0.33 \\
\hline Gymnastics & & & 0.28 & 0.29 \\
\hline Swimming & 0.19 & 0.21 & 0.28 & 0.24 \\
\hline Wrestling & 0.22 & 0.24 & 0.24 & 0.25 \\
\hline \multicolumn{5}{|l|}{ Fall Sports } \\
\hline Baseball & 0.23 & 0.27 & & \\
\hline Soccer & 0.18 & 0.24 & 0.31 & 0.23 \\
\hline Softball & & & 0.26 & 0.32 \\
\hline Tennis & 0.16 & 0.18 & 0.19 & 0.28 \\
\hline Track & 0.17 & 0.25 & 0.24 & 0.32 \\
\hline
\end{tabular}


Table 4

The effect of being in active competition on class absences

\begin{tabular}{lcccc}
\hline \hline Panel A: Boys $(\mathrm{n}=1,382,011)$ & & & & \\
& $(1)$ & $(2)$ & $(3)$ & $(4)$ \\
\cline { 2 - 5 } & & & & \\
Active athlete & $-0.027^{* *}$ & -0.015 & $-0.040^{* * *}$ & $-0.020^{* *}$ \\
& $(0.011)$ & $(0.010)$ & $(0.010)$ & $(0.008)$ \\
Mean out-of-season absences & .39 & .39 & .39 & .39 \\
\% Impact & -7 & -3.8 & -10.3 & -5.2 \\
Student-by-year FE & no & yes & no & yes \\
School-by-week FE & no & no & yes & yes \\
& & & & \\
\hline
\end{tabular}

Panel B: Girls $(\mathrm{n}=1,132,704)$

(1)

$(2)$

(3)

Active athlete

$\begin{array}{cccc}-0.022 & -0.025^{* *} & -0.027^{* *} & -0.013 \\ (0.013) & (0.008) & (0.012) & (0.009)\end{array}$

Mean out-of-season absences

.39

.39

.39

.39

$\%$ Impact

$-5.7$

$-6.3$

$-6.9$

$-3.3$

Student-by-year FE

no

yes

no

yes

School-by-week FE

no

no

yes

yes

Notes: Estimated standard errors are reported in parentheses, adjusted for any clustering at the school level. Percent impacts are relative to the mean number of periods absent among out-of-season athletes. *** significant at $1 \% ;{ }^{* *}$ significant at $5 \%$; ${ }^{*}$ significant at $10 \%$. 
Table 5

The effect of being in active competition on unexcused and excused absences

\begin{tabular}{|c|c|c|}
\hline Panel A: Boys $(\mathrm{n}=1,382,011)$ & $\begin{array}{c}\text { Unexcused } \\
(1)\end{array}$ & $\begin{array}{c}\text { Excused } \\
(2)\end{array}$ \\
\hline Active athlete & $\begin{array}{c}-0.018^{* *} \\
(0.005)\end{array}$ & $\begin{array}{l}-0.003 \\
(0.006)\end{array}$ \\
\hline $\begin{array}{l}\text { Mean out-of-season absences } \\
\text { \% Impact } \\
\text { Student-by-year FE } \\
\text { School-by-week FE }\end{array}$ & $\begin{array}{l}.17 \\
-10.3 \\
\text { yes } \\
\text { yes }\end{array}$ & $\begin{array}{l}.22 \\
-1.3 \\
\text { yes } \\
\text { yes }\end{array}$ \\
\hline Panel B: Girls $(\mathrm{n}=1,132,704)$ & $\begin{array}{c}\text { Unexcused } \\
(1)\end{array}$ & $\begin{array}{c}\text { Excused } \\
(2)\end{array}$ \\
\hline Active athlete & $\begin{array}{l}-0.004 \\
(0.003)\end{array}$ & $\begin{array}{l}-0.009 \\
(0.008)\end{array}$ \\
\hline $\begin{array}{l}\text { Mean out-of-season absences } \\
\% \text { Impact } \\
\text { Student-by-year FE } \\
\text { School-by-week FE }\end{array}$ & $\begin{array}{l}.12 \\
-3.3 \\
\text { yes } \\
\text { yes }\end{array}$ & $\begin{array}{l}.27 \\
-3.3 \\
\text { yes } \\
\text { yes }\end{array}$ \\
\hline $\begin{array}{l}\text { Notes: Estimated standard errors are repor } \\
\text { at the school level. Percent impacts are r } \\
\text { among out-of-season athletes. }{ }^{* * *} \text { significa } \\
10 \% \text {. }\end{array}$ & $\begin{array}{l}\text { ses, adjusted fo } \\
\text { nean number of } \\
\text { snificant at 5\%; }\end{array}$ & $\begin{array}{l}\text { y clustering } \\
\text { iods absent } \\
\text { innificant at }\end{array}$ \\
\hline
\end{tabular}


Table 6

Racial heterogeneity in the effect of active competition on absences

\begin{tabular}{|c|c|c|c|c|}
\hline \multirow[t]{2}{*}{ Panel A: Boys } & \multicolumn{2}{|c|}{ Unexcused } & \multicolumn{2}{|c|}{ Excused } \\
\hline & $\begin{array}{c}\text { White/ } \\
\text { Asian } \\
(1)\end{array}$ & $\begin{array}{c}\text { Black/ } \\
\text { Hispanic } \\
(2)\end{array}$ & $\begin{array}{c}\text { White/ } \\
\text { Asian } \\
(3)\end{array}$ & $\begin{array}{c}\text { Black/ } \\
\text { Hispanic } \\
(4)\end{array}$ \\
\hline Active athlete & $\begin{array}{l}-0.005 \\
(0.005)\end{array}$ & $\begin{array}{c}-0.040^{* * *} \\
(0.007)\end{array}$ & $\begin{array}{l}-0.003 \\
(0.005)\end{array}$ & $\begin{array}{c}-0.003 \\
(0.009)\end{array}$ \\
\hline $\begin{array}{l}\text { Mean out-of-season absences } \\
\% \text { Impact } \\
\text { Observations } \\
\text { Students }\end{array}$ & $\begin{array}{c}.11 \\
-4.9 \\
951,020 \\
5,416\end{array}$ & $\begin{array}{c}.31 \\
-12.8 \\
430,991 \\
2,491\end{array}$ & $\begin{array}{c}.21 \\
-1.4 \\
951,020 \\
5,416\end{array}$ & $\begin{array}{c}.24 \\
-1.2 \\
430,991 \\
2,491\end{array}$ \\
\hline \multirow[t]{2}{*}{ Panel B: Girls } & \multicolumn{2}{|c|}{ Unexcused } & \multicolumn{2}{|c|}{ Excused } \\
\hline & $\begin{array}{c}\text { White/ } \\
\text { Asian } \\
(1)\end{array}$ & $\begin{array}{c}\text { Black/ } \\
\text { Hispanic } \\
(2)\end{array}$ & $\begin{array}{c}\text { White/ } \\
\text { Asian } \\
(3)\end{array}$ & $\begin{array}{c}\text { Black/ } \\
\text { Hispanic } \\
(4)\end{array}$ \\
\hline Active athlete & $\begin{array}{c}-0.001 \\
(0.001)\end{array}$ & $\begin{array}{l}-0.016 \\
(0.010)\end{array}$ & $\begin{array}{l}-0.006 \\
(0.007)\end{array}$ & $\begin{array}{c}-0.017 \\
(0.013)\end{array}$ \\
\hline Mean out-of-season absences & .09 & .22 & .26 & .3 \\
\hline$\%$ Impact & -1.3 & -7.4 & -2.2 & -5.6 \\
\hline Observations & 851,045 & 281,659 & 851,045 & 281,659 \\
\hline Students & 4,840 & 1,613 & 4,840 & 1,613 \\
\hline
\end{tabular}


Table 7

Heterogeneity across family structure in the effect of active participation on absences

\begin{tabular}{|c|c|c|c|c|c|c|}
\hline & \multicolumn{3}{|c|}{ Living with two parents } & \multicolumn{3}{|c|}{ Not living with two parents } \\
\hline & $\begin{array}{l}\text { All } \\
(1)\end{array}$ & $\begin{array}{c}\text { White/ } \\
\text { Asian } \\
(2)\end{array}$ & $\begin{array}{c}\text { Black/ } \\
\text { Hispanic } \\
(3)\end{array}$ & $\begin{array}{l}\text { All } \\
(4)\end{array}$ & $\begin{array}{c}\text { White/ } \\
\text { Asian } \\
(5)\end{array}$ & $\begin{array}{c}\text { Black/ } \\
\text { Hispanic } \\
(6)\end{array}$ \\
\hline Panel A: Boys & \multicolumn{6}{|c|}{ Unexcused Absences } \\
\hline Active athlete & $\begin{array}{l}-0.006 \\
(0.005)\end{array}$ & $\begin{array}{l}-0.004 \\
(0.004)\end{array}$ & $\begin{array}{l}-0.019 \\
(0.010)\end{array}$ & $\begin{array}{c}-0.034^{* * *} \\
(0.007)\end{array}$ & $\begin{array}{l}-0.009 \\
(0.011)\end{array}$ & $\begin{array}{c}-0.048^{* * *} \\
(0.007)\end{array}$ \\
\hline $\begin{array}{l}\text { Mean out-of-season absences } \\
\text { \% Impact }\end{array}$ & $\begin{array}{l}.12 \\
-5.3\end{array}$ & $\begin{array}{l}.09 \\
-4.1\end{array}$ & $\begin{array}{l}.21 \\
-9\end{array}$ & $\begin{array}{c}.29 \\
-11.9\end{array}$ & $\begin{array}{l}.18 \\
-4.8\end{array}$ & $\begin{array}{c}.39 \\
-12.4\end{array}$ \\
\hline & \multicolumn{6}{|c|}{ Excused Absences } \\
\hline Active athlete & $\begin{array}{l}-0.003 \\
(0.006)\end{array}$ & $\begin{array}{l}-0.003 \\
(0.006)\end{array}$ & $\begin{array}{l}-0.004 \\
(0.012)\end{array}$ & $\begin{array}{c}0.000 \\
(0.008)\end{array}$ & $\begin{array}{c}0.001 \\
(0.007)\end{array}$ & $\begin{array}{l}-0.001 \\
(0.011)\end{array}$ \\
\hline $\begin{array}{l}\text { Mean out-of-season absences } \\
\text { \% Impact }\end{array}$ & $\begin{array}{l}.21 \\
-1.6\end{array}$ & $\begin{array}{c}.2 \\
-1.5\end{array}$ & $\begin{array}{l}.23 \\
-1.7\end{array}$ & $\begin{array}{c}.25 \\
0\end{array}$ & $\begin{array}{l}.25 \\
.2\end{array}$ & $\begin{array}{l}.25 \\
-.4\end{array}$ \\
\hline $\begin{array}{l}\text { Observations } \\
\text { Students }\end{array}$ & $\begin{array}{c}954,449 \\
5,434\end{array}$ & $\begin{array}{c}761,856 \\
4,327\end{array}$ & $\begin{array}{c}192,593 \\
1,107\end{array}$ & $\begin{array}{l}427,562 \\
2,473\end{array}$ & $\begin{array}{c}189,164 \\
1,089\end{array}$ & $\begin{array}{c}238,398 \\
1,384\end{array}$ \\
\hline Panel B: Girls & \multicolumn{6}{|c|}{ Unexcused Absences } \\
\hline Active athlete & $\begin{array}{r}-0.003^{*} \\
(0.001)\end{array}$ & $\begin{array}{l}-0.001 \\
(0.001)\end{array}$ & $\begin{array}{c}-0.017^{* * *} \\
(0.004)\end{array}$ & $\begin{array}{l}-0.008 \\
(0.009)\end{array}$ & $\begin{array}{l}-0.002 \\
(0.006)\end{array}$ & $\begin{array}{l}-0.019 \\
(0.018)\end{array}$ \\
\hline $\begin{array}{l}\text { Mean out-of-season absences } \\
\text { \%-Impact }\end{array}$ & $\begin{array}{l}.09 \\
-3.2\end{array}$ & $\begin{array}{l}.07 \\
-.9\end{array}$ & $\begin{array}{c}.15 \\
-11.6\end{array}$ & $\begin{array}{l}.19 \\
-4.3\end{array}$ & $\begin{array}{c}.13 \\
-1.3\end{array}$ & $\begin{array}{l}.28 \\
-6.9\end{array}$ \\
\hline & \multicolumn{6}{|c|}{ Excused Absences } \\
\hline Active athlete & $\begin{array}{l}-0.010 \\
(0.007)\end{array}$ & $\begin{array}{l}-0.007 \\
(0.007)\end{array}$ & $\begin{array}{l}-0.021 \\
(0.014)\end{array}$ & $\begin{array}{l}-0.010 \\
(0.013)\end{array}$ & $\begin{array}{l}-0.004 \\
(0.013)\end{array}$ & $\begin{array}{l}-0.017 \\
(0.022)\end{array}$ \\
\hline $\begin{array}{l}\text { Mean out-of-season absences } \\
\text { \%-Impact }\end{array}$ & $\begin{array}{l}.26 \\
-3.7\end{array}$ & $\begin{array}{l}.25 \\
-2.8\end{array}$ & $\begin{array}{l}.28 \\
-7.5\end{array}$ & $\begin{array}{c}.31 \\
-3.2\end{array}$ & $\begin{array}{c}.3 \\
-1.2\end{array}$ & $\begin{array}{l}.32 \\
-5.2\end{array}$ \\
\hline $\begin{array}{l}\text { Observations } \\
\text { Students }\end{array}$ & $\begin{array}{c}799,453 \\
4,538\end{array}$ & $\begin{array}{c}658,688 \\
3,737\end{array}$ & $\begin{array}{c}140,765 \\
801\end{array}$ & $\begin{array}{c}333,251 \\
1,915\end{array}$ & $\begin{array}{c}192,357 \\
1,103\end{array}$ & $\begin{array}{c}140,894 \\
812\end{array}$ \\
\hline
\end{tabular}


Table 8

Active competition on class absences, by grade level

\begin{tabular}{|c|c|c|c|c|}
\hline \multirow[t]{2}{*}{ Panel A: Boys } & \multicolumn{2}{|c|}{ Grades 9-10 } & \multicolumn{2}{|c|}{ Grades 11-12 } \\
\hline & $\begin{array}{c}\text { Unexcused } \\
(1)\end{array}$ & $\begin{array}{c}\text { Excused } \\
(2)\end{array}$ & $\begin{array}{c}\text { Unexcused } \\
(3)\end{array}$ & $\begin{array}{c}\text { Excused } \\
(4)\end{array}$ \\
\hline Active athlete & $\begin{array}{c}-0.022^{* * *} \\
(0.006)\end{array}$ & $\begin{array}{l}-0.005 \\
(0.008)\end{array}$ & $\begin{array}{c}-0.012^{*} \\
(0.006)\end{array}$ & $\begin{array}{l}-0.002 \\
(0.007)\end{array}$ \\
\hline $\begin{array}{l}\text { Mean out-of-season absences. } \\
\text { \% Impact } \\
\text { Observations } \\
\text { Students }\end{array}$ & $\begin{array}{c}.15 \\
-14.6 \\
752,462 \\
4,298\end{array}$ & $\begin{array}{c}.21 \\
-2.4 \\
752,462 \\
4,298\end{array}$ & $\begin{array}{c}.2 \\
-6.1 \\
629,549 \\
3,609\end{array}$ & $\begin{array}{c}.23 \\
-.8 \\
629,549 \\
3,609\end{array}$ \\
\hline Panel B: Girls & $\begin{array}{l}\text { Grades } \\
\text { Unexcused } \\
(1)\end{array}$ & $\begin{array}{l}9-10 \\
\text { Excused } \\
\quad(2) \\
\end{array}$ & $\begin{array}{c}\text { Grades } \\
\text { Unexcused } \\
(3)\end{array}$ & $\begin{array}{l}\text { 11-12 } \\
\text { Excused } \\
(4)\end{array}$ \\
\hline Active athlete & $\begin{array}{c}-0.005^{*} \\
(0.003)\end{array}$ & $\begin{array}{c}-0.017^{*} \\
(0.009)\end{array}$ & $\begin{array}{l}-0.003 \\
(0.005)\end{array}$ & $\begin{array}{l}-0.000 \\
(0.007)\end{array}$ \\
\hline $\begin{array}{l}\text { Mean out-of-season absences } \\
\text { \% Impact } \\
\text { Observations } \\
\text { Students }\end{array}$ & $\begin{array}{c}.09 \\
-5.9 \\
637,870 \\
3,625\end{array}$ & $\begin{array}{c}.25 \\
-6.9 \\
637,870 \\
3,625\end{array}$ & $\begin{array}{c}.15 \\
-1.9 \\
494,834 \\
2,828\end{array}$ & $\begin{array}{c}.3 \\
-.1 \\
494,834 \\
2,828\end{array}$ \\
\hline
\end{tabular}


Table 9

Game-day effects of active sports participation on class absences

\begin{tabular}{lcccc}
\hline \hline \multirow{2}{*}{ Panel A: Boys $(\mathrm{n}=1,382,011)$} & \multicolumn{2}{c}{ Unexcused } & \multicolumn{2}{c}{ Excused } \\
& $(1)$ & $(2)$ & $(3)$ & $(4)$ \\
\cline { 2 - 5 } Active athlete & $-0.016^{* * *}$ & $-0.013^{* *}$ & -0.001 & -0.003 \\
& $(0.005)$ & $(0.004)$ & $(0.005)$ & $(0.005)$ \\
Active $\times$ GameDay -1 & $-0.004^{*}$ & $-0.006^{* *}$ & -0.007 & -0.006 \\
& $(0.002)$ & $(0.002)$ & $(0.004)$ & $(0.004)$ \\
Active $\times$ GameDay & $-0.019^{* * *}$ & $-0.026^{* * *}$ & -0.020 & -0.017 \\
& $(0.005)$ & $(0.006)$ & $(0.026)$ & $(0.026)$ \\
Active $\times$ GameDay +1 & $0.021^{* * *}$ & $0.014^{* * *}$ & $0.030^{* * *}$ & $0.034^{* * *}$ \\
& $(0.005)$ & $(0.003)$ & $(0.005)$ & $(0.004)$ \\
Mean out-of-season absences & .17 & & & .17 \\
Day-of-week FE & no & yes & .22 & no \\
& & & & yes \\
\hline
\end{tabular}

Panel B: Girls (n=1,132,704)

Unexcused

(1)

Active athlete

Active $\times$ GameDay -1

Active $\times$ GameDay

Active $\times$ GameDay +1

\begin{tabular}{cccc}
$(1)$ & $(2)$ & $(3)$ & $(4)$ \\
\hline & & & \\
-0.005 & -0.005 & -0.005 & -0.007 \\
$(0.003)$ & $(0.003)$ & $(0.005)$ & $(0.005)$ \\
0.002 & 0.005 & 0.003 & 0.006 \\
$(0.003)$ & $(0.003)$ & $(0.005)$ & $(0.005)$ \\
$-0.006^{*}$ & $-0.007^{* *}$ & $-0.037^{*}$ & $-0.033^{*}$ \\
$(0.003)$ & $(0.003)$ & $(0.017)$ & $(0.017)$ \\
$0.014^{* * *}$ & $0.008^{* *}$ & $0.018^{* *}$ & $0.020^{* *}$ \\
$(0.003)$ & $(0.003)$ & $(0.008)$ & $(0.007)$
\end{tabular}

Mean out-of-season absences

Day-of-week FE

.12

no

\begin{abstract}
.12
\end{abstract}
yes
.27

no
.27

yes

\footnotetext{
Notes: All specifications include student-by-year, and school-by-week fixed effects. Estimated standard errors are reported in parentheses, adjusted for any clustering at the school level. *** significant at $1 \%$; ** significant at $5 \%$; * significant at $10 \%$.
} 
Table 10

Game-day effects by sport, boys

\begin{tabular}{|c|c|c|c|c|c|}
\hline Panel A: Boys ( $\mathrm{n}=1,382,011)$ & $\begin{array}{l}\text { Unexcused } \\
(1)\end{array}$ & $\begin{array}{c}\text { Excused } \\
(2)\end{array}$ & & $\begin{array}{l}\text { Unexcused } \\
(1)\end{array}$ & $\begin{array}{c}\text { Excused } \\
(2)\end{array}$ \\
\hline Active $\times$ Baseball & $\begin{array}{c}-0.027^{* * *} \\
(0.008)\end{array}$ & $\begin{array}{r}-0.020^{*} \\
(0.009)\end{array}$ & Active $\times$ Soccer & $\begin{array}{l}-0.021^{*} \\
(0.010)\end{array}$ & $\begin{array}{l}-0.021 \\
(0.012)\end{array}$ \\
\hline Baseball $\times$ GameDay -1 & $\begin{array}{l}-0.007 \\
(0.005)\end{array}$ & $\begin{array}{c}0.001 \\
(0.010)\end{array}$ & Soccer $\times$ GameDay -1 & $\begin{array}{l}-0.008 \\
(0.007)\end{array}$ & $\begin{array}{l}0.017^{*} \\
(0.009)\end{array}$ \\
\hline Baseball × GameDay & $\begin{array}{c}-0.029^{* *} \\
(0.010)\end{array}$ & $\begin{array}{l}-0.026 \\
(0.031)\end{array}$ & Soccer $\times$ GameDay & $\begin{array}{l}-0.017 \\
(0.010)\end{array}$ & $\begin{array}{l}-0.001 \\
(0.033)\end{array}$ \\
\hline Baseball $\times$ GameDay +1 & $\begin{array}{c}0.001 \\
(0.003)\end{array}$ & $\begin{array}{c}0.012 \\
(0.008)\end{array}$ & Soccer $\times$ GameDay +1 & $\begin{array}{c}0.012 \\
(0.012)\end{array}$ & $\begin{array}{c}0.017 \\
(0.012)\end{array}$ \\
\hline Active $\times$ Basketball & $\begin{array}{c}-0.012^{* *} \\
(0.005)\end{array}$ & $\begin{array}{l}-0.019 \\
(0.013)\end{array}$ & Active $\times$ Swimming & $\begin{array}{l}0.010 \\
(0.006)\end{array}$ & $\begin{array}{l}-0.006 \\
(0.008)\end{array}$ \\
\hline Basketball $\times$ GameDay -1 & $\begin{array}{l}-0.003 \\
(0.007)\end{array}$ & $\begin{array}{l}0.015 \\
(0.029)\end{array}$ & Swimming $\times$ GameDay -1 & $\begin{array}{l}0.003 \\
(0.007)\end{array}$ & $\begin{array}{c}-0.052^{* * * *} \\
(0.010)\end{array}$ \\
\hline Basketball × GameDay & $\begin{array}{c}-0.062^{* * *} \\
(0.011)\end{array}$ & $\begin{array}{l}-0.021 \\
(0.053)\end{array}$ & Swimming $\times$ GameDay & $\begin{array}{c}0.011 \\
(0.007)\end{array}$ & $\begin{array}{l}0.008 \\
(0.021)\end{array}$ \\
\hline Basketball $\times$ GameDay +1 & $\begin{array}{r}0.025^{* *} \\
(0.011)\end{array}$ & $\begin{array}{c}0.079 * * \\
(0.029)\end{array}$ & Swimming $\times$ GameDay +1 & $\begin{array}{l}0.006 \\
(0.005)\end{array}$ & $\begin{array}{c}0.025 \\
(0.047)\end{array}$ \\
\hline Active $\times$ Cross Country & $\begin{array}{c}0.027^{* * *} \\
(0.008)\end{array}$ & $\begin{array}{l}-0.011 \\
(0.007)\end{array}$ & Active $\times$ Tennis & $\begin{array}{c}-0.018 \\
(0.017)\end{array}$ & $\begin{array}{c}0.000 \\
(0.012)\end{array}$ \\
\hline Cross Country $\times$ GameDay -1 & $\begin{array}{l}0.011^{*} \\
(0.005)\end{array}$ & $\begin{array}{c}0.002 \\
(0.009)\end{array}$ & Tennis $\times$ GameDay -1 & $\begin{array}{l}0.007 \\
(0.005)\end{array}$ & $\begin{array}{l}-0.026 \\
(0.018)\end{array}$ \\
\hline Cross Country $\times$ GameDay & $\begin{array}{c}0.034^{* * *} \\
(0.006)\end{array}$ & $\begin{array}{c}0.036 \\
(0.032)\end{array}$ & Tennis $\times$ GameDay & $\begin{array}{l}0.018 \\
(0.011)\end{array}$ & $\begin{array}{c}0.012 \\
(0.028)\end{array}$ \\
\hline Cross Country $\times$ GameDay +1 & $\begin{array}{c}0.019 * * \\
(0.006)\end{array}$ & $\begin{array}{c}0.036 \\
(0.020)\end{array}$ & Tennis $\times$ GameDay +1 & $\begin{array}{c}0.002 \\
(0.006)\end{array}$ & $\begin{array}{l}-0.006 \\
(0.016)\end{array}$ \\
\hline Active $\times$ Football & $\begin{array}{c}-0.037^{* *} \\
(0.012)\end{array}$ & $\begin{array}{c}0.027^{* *} \\
(0.009)\end{array}$ & Active $\times$ Track & $\begin{array}{r}-0.025^{*} \\
(0.011)\end{array}$ & $\begin{array}{c}0.011 \\
(0.015)\end{array}$ \\
\hline Football $\times$ GameDay -1 & $\begin{array}{c}-0.029^{* *} \\
(0.010)\end{array}$ & $\begin{array}{c}-0.040^{* * *} \\
(0.012)\end{array}$ & Track $\times$ GameDay -1 & $\begin{array}{c}-0.021^{* *} \\
(0.009)\end{array}$ & $\begin{array}{l}-0.025^{*} \\
(0.013)\end{array}$ \\
\hline Football $\times$ GameDay & $\begin{array}{c}-0.038^{* * *} \\
(0.011)\end{array}$ & $\begin{array}{c}-0.072^{* * *} \\
(0.020)\end{array}$ & Track $\times$ GameDay & $\begin{array}{c}0.004 \\
(0.011)\end{array}$ & $\begin{array}{l}-0.010 \\
(0.022)\end{array}$ \\
\hline Football $\times$ GameDay +1 & $\begin{array}{c}0.129^{* * *} \\
(0.038)\end{array}$ & $\begin{array}{c}0.183^{* * *} \\
(0.047)\end{array}$ & Track $\times$ GameDay +1 & $\begin{array}{c}0.037^{* *} \\
(0.013)\end{array}$ & $\begin{array}{l}0.036^{* *} \\
(0.013)\end{array}$ \\
\hline Active $\times$ Golf & $\begin{array}{l}0.023^{*} \\
(0.012)\end{array}$ & $\begin{array}{c}0.010 \\
(0.012)\end{array}$ & Active $\times$ Wrestling & $\begin{array}{l}0.008 \\
(0.009)\end{array}$ & $\begin{array}{l}-0.002 \\
(0.009)\end{array}$ \\
\hline Golf $\times$ GameDay -1 & $\begin{array}{c}0.007 \\
(0.005)\end{array}$ & $\begin{array}{l}-0.016 \\
(0.027)\end{array}$ & Wrestling $\times$ GameDay -1 & $\begin{array}{l}0.006 \\
(0.015)\end{array}$ & $\begin{array}{l}-0.009 \\
(0.011)\end{array}$ \\
\hline Golf $\times$ GameDay & $\begin{array}{c}0.014 \\
(0.009)\end{array}$ & $\begin{array}{l}-0.008 \\
(0.030)\end{array}$ & Wrestling $\times$ GameDay & $\begin{array}{l}-0.005 \\
(0.016)\end{array}$ & $\begin{array}{l}-0.016 \\
(0.016)\end{array}$ \\
\hline Golf $\times$ GameDay +1 & $\begin{array}{l}-0.002 \\
(0.006)\end{array}$ & $\begin{array}{l}-0.021 \\
(0.015)\end{array}$ & Wrestling $\times$ GameDay +1 & $\begin{array}{c}0.023 \\
(0.018)\end{array}$ & $\begin{array}{c}0.024^{* *} \\
(0.010)\end{array}$ \\
\hline
\end{tabular}

Notes: All specifications include student-by-year, and school-by-week fixed effects. Estimated standard errors are reported in parentheses, adjusted for any clustering at the school level. ${ }^{* *}$ significant at $1 \%$; ${ }^{* *}$ significant at $5 \%$; ${ }^{*}$ significant at $10 \%$. 
Table 11

Game-day effects by sport, girls

\begin{tabular}{|c|c|c|c|c|c|}
\hline Panel A: Girls $(\mathrm{n}=1,132,704)$ & $\begin{array}{l}\text { Unexcused } \\
\quad(1)\end{array}$ & $\begin{array}{l}\text { Excused } \\
(2)\end{array}$ & & $\begin{array}{l}\text { Unexcused } \\
\quad(1)\end{array}$ & $\begin{array}{l}\text { Excused } \\
(2)\end{array}$ \\
\hline Active $\times$ Basketball & $\begin{array}{l}-0.014 \\
(0.012)\end{array}$ & $\begin{array}{c}0.001 \\
(0.008)\end{array}$ & Active $\times$ Swimming & $\begin{array}{c}0.013^{* * *} \\
(0.004)\end{array}$ & $\begin{array}{c}-0.012 \\
(0.007)\end{array}$ \\
\hline Basketball × GameDay -1 & $\begin{array}{l}-0.012 \\
(0.013)\end{array}$ & $\begin{array}{c}0.013 \\
(0.023)\end{array}$ & Swimming $\times$ GameDay -1 & $\begin{array}{l}-0.006 \\
(0.005)\end{array}$ & $\begin{array}{c}0.019 \\
(0.015)\end{array}$ \\
\hline Basketball × GameDay & $\begin{array}{c}-0.043^{* * *} \\
(0.010)\end{array}$ & $\begin{array}{c}-0.057^{* *} \\
(0.023)\end{array}$ & Swimming $\times$ GameDay & $\begin{array}{l}0.014^{*} \\
(0.007)\end{array}$ & $\begin{array}{c}0.004 \\
(0.020)\end{array}$ \\
\hline Basketball × GameDay +1 & $\begin{array}{c}0.029^{* *} \\
(0.010)\end{array}$ & $\begin{array}{c}0.087^{* * *} \\
(0.019)\end{array}$ & Swimming $\times$ GameDay +1 & $\begin{array}{c}0.009 \\
(0.011)\end{array}$ & $\begin{array}{c}0.011 \\
(0.030)\end{array}$ \\
\hline Active $\times$ Cross Country & $\begin{array}{c}0.009 \\
(0.008)\end{array}$ & $\begin{array}{l}-0.007 \\
(0.006)\end{array}$ & Active $\times$ Tennis & $\begin{array}{c}-0.030^{* * *} \\
(0.009)\end{array}$ & $\begin{array}{l}-0.007 \\
(0.007)\end{array}$ \\
\hline Cross Country $\times$ GameDay -1 & $\begin{array}{l}-0.001 \\
(0.007)\end{array}$ & $\begin{array}{l}-0.036^{*} \\
(0.017)\end{array}$ & Tennis $\times$ GameDay -1 & $\begin{array}{c}0.011^{*} \\
(0.006)\end{array}$ & $\begin{array}{l}-0.000 \\
(0.017)\end{array}$ \\
\hline Cross Country $\times$ GameDay & $\begin{array}{c}0.019^{* * *} \\
(0.005)\end{array}$ & $\begin{array}{l}-0.019 \\
(0.032)\end{array}$ & Tennis $\times$ GameDay & $\begin{array}{c}0.006 \\
(0.006)\end{array}$ & $\begin{array}{c}0.009 \\
(0.026)\end{array}$ \\
\hline Cross Country $\times$ GameDay +1 & $\begin{array}{c}0.002 \\
(0.004)\end{array}$ & $\begin{array}{c}0.029 \\
(0.017)\end{array}$ & Tennis $\times$ GameDay +1 & $\begin{array}{c}0.007 \\
(0.013)\end{array}$ & $\begin{array}{l}-0.003 \\
(0.013)\end{array}$ \\
\hline Active $\times$ Golf & $\begin{array}{c}0.012 \\
(0.013)\end{array}$ & $\begin{array}{c}0.033 \\
(0.019)\end{array}$ & Active $\times$ Track & $\begin{array}{l}-0.006 \\
(0.011)\end{array}$ & $\begin{array}{l}-0.012 \\
(0.015)\end{array}$ \\
\hline Golf $\times$ GameDay -1 & $\begin{array}{l}-0.022 \\
(0.013)\end{array}$ & $\begin{array}{l}-0.040 \\
(0.031)\end{array}$ & Track × GameDay -1 & $\begin{array}{l}-0.017 \\
(0.010)\end{array}$ & $\begin{array}{c}-0.034^{*} \\
(0.018)\end{array}$ \\
\hline Golf $\times$ GameDay & $\begin{array}{l}-0.005 \\
(0.020)\end{array}$ & $\begin{array}{l}-0.044 \\
(0.032)\end{array}$ & Track $\times$ GameDay & $\begin{array}{l}-0.001 \\
(0.009)\end{array}$ & $\begin{array}{l}-0.017 \\
(0.016)\end{array}$ \\
\hline Golf $\times$ GameDay +1 & $\begin{array}{c}0.039 * * \\
(0.016)\end{array}$ & $\begin{array}{c}0.011 \\
(0.026)\end{array}$ & Track $\times$ GameDay +1 & $\begin{array}{c}0.045^{* * *} * \\
(0.013)\end{array}$ & $\begin{array}{c}0.059 * * \\
(0.023)\end{array}$ \\
\hline Active $\times$ Gymnastics & $\begin{array}{c}0.011 \\
(0.007)\end{array}$ & $\begin{array}{c}0.015 \\
(0.013)\end{array}$ & Active $\times$ Volleyball & $\begin{array}{c}0.004 \\
(0.004)\end{array}$ & $\begin{array}{l}-0.017 \\
(0.010)\end{array}$ \\
\hline Gymnastics $\times$ GameDay -1 & $\begin{array}{c}0.027 \\
(0.017)\end{array}$ & $\begin{array}{l}-0.028 \\
(0.024)\end{array}$ & Volleyball × GameDay -1 & $\begin{array}{l}-0.004 \\
(0.004)\end{array}$ & $\begin{array}{l}-0.012 \\
(0.008)\end{array}$ \\
\hline Gymnastics $\times$ GameDay & $\begin{array}{c}0.005 \\
(0.012)\end{array}$ & $\begin{array}{l}-0.023 \\
(0.036)\end{array}$ & Volleyball × GameDay & $\begin{array}{c}-0.016^{* * *} \\
(0.005)\end{array}$ & $\begin{array}{c}-0.063^{* * *} \\
(0.015)\end{array}$ \\
\hline Gymnastics $\times$ GameDay +1 & $\begin{array}{c}0.000 \\
(0.010)\end{array}$ & $\begin{array}{c}0.061^{* *} \\
(0.021)\end{array}$ & Volleyball $\times$ GameDay +1 & $\begin{array}{c}0.013 \\
(0.008)\end{array}$ & $\begin{array}{c}0.017 \\
(0.011)\end{array}$ \\
\hline Active $\times$ Soccer & $\begin{array}{c}0.017^{* *} \\
(0.007)\end{array}$ & $\begin{array}{l}-0.003 \\
(0.010)\end{array}$ & Active $\times$ Wrestling & $\begin{array}{l}0.032^{*} \\
(0.015)\end{array}$ & $\begin{array}{l}-0.023 \\
(0.029)\end{array}$ \\
\hline Soccer $\times$ GameDay -1 & $\begin{array}{c}0.002 \\
(0.004)\end{array}$ & $\begin{array}{c}0.012 \\
(0.009)\end{array}$ & Wrestling $\times$ GameDay -1 & $\begin{array}{c}0.022 \\
(0.039)\end{array}$ & $\begin{array}{c}0.048 \\
(0.035)\end{array}$ \\
\hline Soccer $\times$ GameDay & $\begin{array}{c}0.009 \\
(0.005)\end{array}$ & $\begin{array}{l}-0.028 \\
(0.015)\end{array}$ & Wrestling $\times$ GameDay & $\begin{array}{l}-0.029 \\
(0.029)\end{array}$ & $\begin{array}{c}0.042 \\
(0.032)\end{array}$ \\
\hline Soccer $\times$ GameDay +1 & $\begin{array}{c}0.006^{* *} \\
(0.002)\end{array}$ & $\begin{array}{l}-0.004 \\
(0.010)\end{array}$ & Wrestling $\times$ GameDay +1 & $\begin{array}{c}0.024 \\
(0.033)\end{array}$ & $\begin{array}{c}0.082^{* *} \\
(0.029)\end{array}$ \\
\hline Active $\times$ Softball & $\begin{array}{c}-0.026^{* *} \\
(0.009)\end{array}$ & $\begin{array}{l}-0.015 \\
(0.015)\end{array}$ & & & \\
\hline Softball $\times$ GameDay -1 & $\begin{array}{c}0.000 \\
(0.011)\end{array}$ & $\begin{array}{l}-0.015 \\
(0.009)\end{array}$ & & & \\
\hline Softball $\times$ GameDay & $\begin{array}{l}-0.000 \\
(0.011)\end{array}$ & $\begin{array}{l}-0.048 \\
(0.029)\end{array}$ & & & \\
\hline Softball × GameDay +1 & $\begin{array}{c}0.005 \\
(0.007)\end{array}$ & $\begin{array}{l}-0.017 \\
(0.013)\end{array}$ & & & \\
\hline
\end{tabular}

Notes: All specifications include student-by-year, and school-by-week fixed effects. Estimated standard errors are reported in

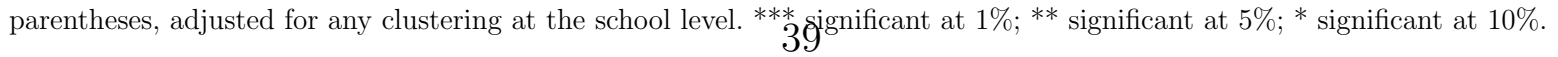


Table 12

Game-day effects of active sports participation on school-nurse visits

\begin{tabular}{lcc}
\hline \hline & \multicolumn{2}{c}{ Nurse Visits } \\
Panel A: Boys $(\mathrm{n}=1,382,011)$ & $(1)$ & $(2)$ \\
\cline { 2 - 3 } Active athlete & 0.00016 & 0.00015 \\
& $(0.00013)$ & $(0.00013)$ \\
Active $\times$ GameDay -1 & 0.00008 & 0.00008 \\
& $(0.00013)$ & $(0.00012)$ \\
Active $\times$ GameDay & $-0.00019^{* *}$ & $-0.00017^{* *}$ \\
& $(0.00006)$ & $(0.00008)$ \\
Active $\times$ GameDay +1 & $0.00029^{*}$ & $0.00033^{* *}$ \\
& $(0.00016)$ & $(0.00014)$ \\
Daily Pr[Nurse Visit] & .0013 & .0013 \\
Day-of-week FE & no & yes \\
\end{tabular}

Panel B: Girls (n=1,143,213)

Nurse Visits

Active athlete

$0.00014 \quad 0.00013$

Active $\times$ GameDay -1

$(0.00011) \quad(0.00012)$

$0.00008 \quad 0.00007$

$(0.00008) \quad(0.00007)$

Active $\times$ GameDay

$-0.00003 \quad-0.00001$

Active $\times$ GameDay +1

$(0.00008) \quad(0.00008)$

$-0.00006 \quad 0.00001$

$(0.00018) \quad(0.00018)$

Daily $\operatorname{Pr}$ [Nurse Visit]

Day-of-week FE

$\begin{array}{cc}.0014 & .0014 \\ \text { no } & \text { yes }\end{array}$

Notes: All specifications include student-by-year, and school-by-week fixed effects. Estimated standard errors are reported in parentheses, adjusted for any clustering at the school level. ${ }^{* * *}$ significant at $1 \%$; ** significant at $5 \% ; *$ significant at $10 \%$. 
Table 13

Does the degree of active participation in a semester change final course grades?

\begin{tabular}{|c|c|c|c|c|}
\hline Panel A: Boys $(\mathrm{n}=89,807)$ & $(1)$ & $(2)$ & $(3)$ & $(4)$ \\
\hline Prop. semester active & $\begin{array}{c}0.095^{* *} \\
(0.037)\end{array}$ & $\begin{array}{l}0.022^{* *} \\
(0.007)\end{array}$ & $\begin{array}{c}0.077^{* *} \\
(0.028)\end{array}$ & $\begin{array}{c}0.007 \\
(0.010)\end{array}$ \\
\hline $\begin{array}{l}\text { Mean out-of-season grade } \\
\% \text { Impact }\end{array}$ & 2.98 & 2.98 & 2.98 & 2.98 \\
\hline Student FE & no & yes & no & yes \\
\hline Course-by-semester-by-school FE & no & no & yes & yes \\
\hline Panel B: Girls $(\mathrm{n}=73,841)$ & $(1)$ & $(2)$ & $(3)$ & $(4)$ \\
\hline Prop. semester active & $\begin{array}{c}0.055 \\
(0.042)\end{array}$ & $\begin{array}{c}0.012 \\
(0.012)\end{array}$ & $\begin{array}{c}0.078 * * * \\
(0.024)\end{array}$ & $\begin{array}{l}-0.006 \\
(0.010)\end{array}$ \\
\hline $\begin{array}{l}\text { Mean out-of-season grade } \\
\% \text { Impact }\end{array}$ & 3.38 & 3.38 & 3.38 & 3.38 \\
\hline Student FE & no & yes & no & yes \\
\hline Course-by-semester-by-school FE & no & no & yes & yes \\
\hline
\end{tabular}


Table 14

Racial heterogeneity in the effect of active participation on grades

\begin{tabular}{|c|c|c|}
\hline Panel A: Boys & $\begin{array}{c}\text { White/ } \\
\text { Asian } \\
(1)\end{array}$ & $\begin{array}{c}\text { Black/ } \\
\text { Hispanic } \\
(2)\end{array}$ \\
\hline Prop. semester active & $\begin{array}{l}-0.012 \\
(0.012)\end{array}$ & $\begin{array}{c}0.058^{* * *} \\
(0.018)\end{array}$ \\
\hline $\begin{array}{l}\text { Mean out-of-season grade } 4.0 \\
\text { Observations }\end{array}$ & $\begin{array}{c}3.18 \\
61,666\end{array}$ & $\begin{array}{c}2.5 \\
28,141\end{array}$ \\
\hline Panel B: Girls & $\begin{array}{c}\text { White/ } \\
\text { Asian } \\
(1)\end{array}$ & $\begin{array}{c}\text { Black/ } \\
\text { Hispanic } \\
(2)\end{array}$ \\
\hline Prop. semester active & $\begin{array}{l}-0.017^{*} \\
(0.009)\end{array}$ & $\begin{array}{c}0.008 \\
(0.023)\end{array}$ \\
\hline $\begin{array}{l}\text { Mean out-of-season grade } 4.0 \\
\text { Observations }\end{array}$ & $\begin{array}{c}3.51 \\
55,441\end{array}$ & $\begin{array}{c}2.93 \\
18,400\end{array}$ \\
\hline
\end{tabular}


Table 15

Heterogeneity across family structure in the effect of active participation on grades

\begin{tabular}{|c|c|c|c|c|c|c|}
\hline \multirow[b]{2}{*}{ Panel A: Boys } & \multicolumn{3}{|c|}{ Living with two parents } & \multicolumn{3}{|c|}{ Not living with two parents } \\
\hline & $\begin{array}{l}\text { All } \\
(1)\end{array}$ & $\begin{array}{c}\text { White/ } \\
\text { Asian } \\
(2)\end{array}$ & $\begin{array}{c}\text { Black/ } \\
\text { Hispanic } \\
(3)\end{array}$ & $\begin{array}{l}\text { All } \\
(4)\end{array}$ & $\begin{array}{c}\text { White/ } \\
\text { Asian } \\
(5)\end{array}$ & $\begin{array}{c}\text { Black/ } \\
\text { Hispanic } \\
(6)\end{array}$ \\
\hline Prop. semester active & $\begin{array}{l}-0.009 \\
(0.010)\end{array}$ & $\begin{array}{r}-0.017^{*} \\
(0.009)\end{array}$ & $\begin{array}{c}0.035 \\
(0.052)\end{array}$ & $\begin{array}{l}0.046^{*} \\
(0.022)\end{array}$ & $\begin{array}{c}0.022 \\
(0.037)\end{array}$ & $\begin{array}{r}0.087^{* * *} \\
(0.024)\end{array}$ \\
\hline $\begin{array}{l}\text { Mean out-of-season grade } 4.0 \\
\text { Observations }\end{array}$ & $\begin{array}{c}3.15 \\
61,984\end{array}$ & $\begin{array}{c}3.27 \\
49,405\end{array}$ & $\begin{array}{c}2.68 \\
12,579\end{array}$ & $\begin{array}{c}2.59 \\
27,823\end{array}$ & $\begin{array}{c}2.86 \\
12,261\end{array}$ & $\begin{array}{c}2.35 \\
15,562\end{array}$ \\
\hline Panel B: Girls & $(1)$ & $(2)$ & $(3)$ & $(4)$ & $(5)$ & $(6)$ \\
\hline Prop. semester active & $\begin{array}{c}0.002 \\
(0.009)\end{array}$ & $\begin{array}{l}-0.003 \\
(0.011)\end{array}$ & $\begin{array}{l}-0.000 \\
(0.040)\end{array}$ & $\begin{array}{l}-0.023 \\
(0.023)\end{array}$ & $\begin{array}{c}-0.052^{* *} \\
(0.023)\end{array}$ & $\begin{array}{c}0.003 \\
(0.074)\end{array}$ \\
\hline $\begin{array}{l}\text { Mean out-of-season grade } 4.0 \\
\text { Observations }\end{array}$ & $\begin{array}{c}3.38 \\
52,153\end{array}$ & $\begin{array}{c}3.56 \\
42,949\end{array}$ & $\begin{array}{c}3.1 \\
9,204\end{array}$ & $\begin{array}{c}3.12 \\
21,688\end{array}$ & $\begin{array}{c}3.34 \\
12,492\end{array}$ & $\begin{array}{c}2.75 \\
9,196\end{array}$ \\
\hline
\end{tabular}

Notes: All regressions include student, school-year-semester-course, and grade FEs. Estimated standard errors are reported in parentheses, adjusted for any clustering at the school level. *** significant at $1 \%$; ** significant at $5 \%$; ${ }^{*}$ significant at $10 \%$. 
Figure 1

Mean daily absences by week, by gender
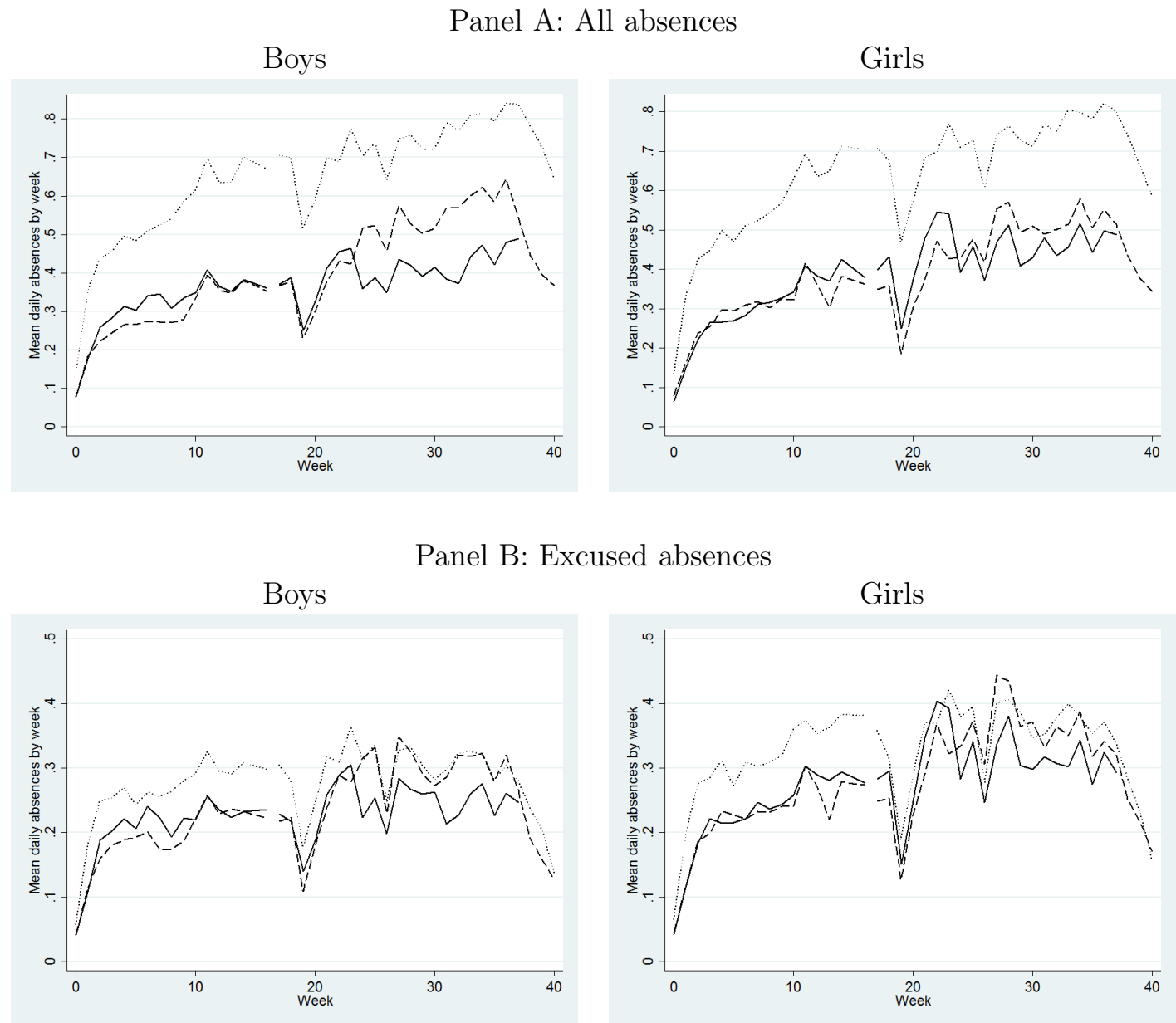

Panel B: Unexcused absences

Boys

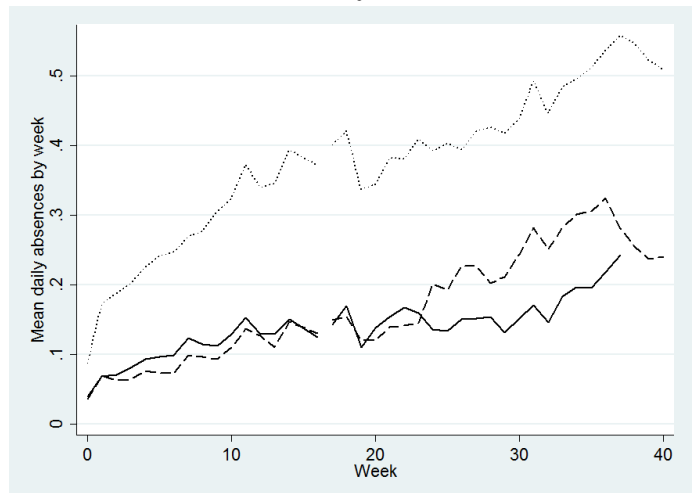

Girls

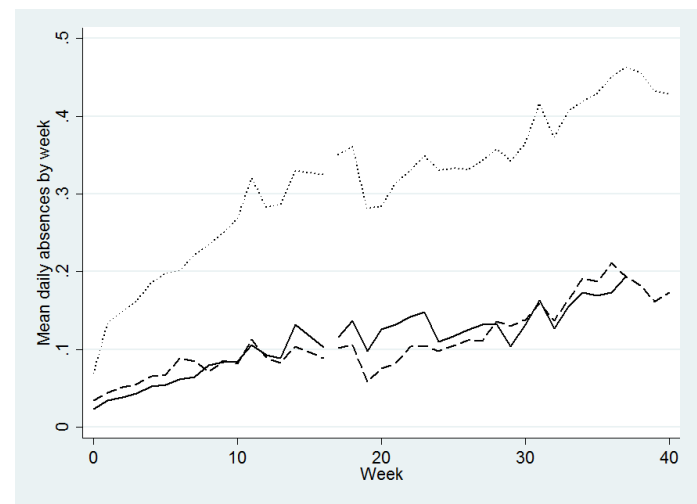




\section{Appendix}

Table A1

Standard-error sensitivity around the effect of being in active competition on unexcused and excused absences

\begin{tabular}{|c|c|c|}
\hline Panel A: Boys $(n=1,382,011)$ & $\begin{array}{c}\text { Unexcused } \\
(1)\end{array}$ & $\begin{array}{c}\text { Excused } \\
(2)\end{array}$ \\
\hline Active Athlete & -0.018 & -0.003 \\
\hline $\begin{array}{l}\text { Standard-error estimates: } \\
\text { IID } \\
\text { Individual } \\
\text { School-by-week } \\
\text { School-by-year } \\
\text { School }\end{array}$ & $\begin{array}{c}0.001^{* * *} \\
0.003^{* * *} \\
0.002^{* * *} \\
0.004^{* * *} \\
0.005^{* *}\end{array}$ & $\begin{array}{l}0.002 \\
0.004 \\
0.003 \\
0.005 \\
0.006\end{array}$ \\
\hline Ibragimov-Müller (95\% CI) & {$[-0.035,-0.009]$} & {$[-0.022,0.012]$} \\
\hline $\begin{array}{l}\text { Panel B: Girls ( } \mathrm{n}=1,132,704) \\
\text { Active Athlete }\end{array}$ & $\begin{array}{l}\text { Unexcused } \\
\qquad(1) \\
-0.004\end{array}$ & $\begin{array}{c}\text { Excused } \\
(2) \\
-0009\end{array}$ \\
\hline $\begin{array}{l}\text { Standard-error estimates: } \\
\text { IID } \\
\text { Individual } \\
\text { School-by-week } \\
\text { School-by-year } \\
\text { School }\end{array}$ & $\begin{array}{c}0.001^{* * *} \\
0.002^{*} \\
0.002^{* *} \\
0.002 \\
0.003\end{array}$ & $\begin{array}{c}0.003^{* * *} \\
0.004^{* *} \\
0.004^{* *} \\
0.006 \\
0.008\end{array}$ \\
\hline Ibragimov-Müller (95\% CI) & {$[-0.021,0.005]$} & {$[-0.038,0.012]$} \\
\hline
\end{tabular}


Table A2

Standard-error sensitivity around the effect of being in active competition on final course grades

\begin{tabular}{lc}
\hline \hline & \\
Panel A: Boys $(\mathrm{n}=89,807)$ & $(1)$ \\
\cline { 2 - 2 } Prop. semester active & 0.007 \\
& \\
Standard-error estimates: & 0.009 \\
IID & 0.010 \\
Individual & 0.011 \\
School-by-semester & 0.011 \\
School-by-year & 0.010 \\
School & {$[-0.010,0.039]$} \\
& \\
\hline
\end{tabular}

Panel B: Girls $(\mathrm{n}=73,841)$

Prop. semester active

$-0.006$

Standard-error estimates:

$\begin{array}{ll}\text { IID } & 0.008 \\ \text { Individual } & 0.009 \\ \text { School-by-semester } & 0.009 \\ \text { School-by-year } & 0.010 \\ \text { School } & 0.010\end{array}$

Ibragimov-Müller (95\% CI) $\quad[-0.027,0.039]$

Notes: All specifications include student, school-by-semester-by-course, and grade fixed effects. Ibragimov-Müller confidence intervals follow Ibragimov and Müller (2010) and Ibragimov and Müller (2013). ${ }^{* * *}$ significant at $1 \% ; * *$ significant at $5 \%$; ${ }^{*}$ significant at $10 \%$. 